\title{
Farklı Akım Koşullarına Sahip Serbest Hidrolik Sıçramanın Deneysel ve Sayısal Modellemesi
}

\author{
Veysel GÜMÜŞ ${ }^{1 *}$, Mehmet PARMAKSIZ² $^{2}$ Oğuz ŞİMŞEK ${ }^{3}$, Yavuz AVŞAROĞLU ${ }^{4}$ \\ Geliş / Received: 18/10/2019 \\ Revize / Revised: 25/11/2019 \\ Kabul / Accepted:25/11/2019
}

\section{ÖZ}

Akımın kritik üstü akımdan kritik altı akıma hızlı bir geçişi olarak tanımlanan hidrolik sıçrama, genellikle dolusavaklardan yüksek hızlarda tahliye edilen suyun enerjisini azaltmak için kullanılır. Karmaşık bir yapıya sahip olan hidrolik sıçramanın karakteristiklerinin bilinmesi enerji kırıcı yapıların tasarımı açısından önemlidir. Bu çalışmada, farklı akım koşullarında meydana gelen hidrolik sıçramanın deneysel ve sayısal modellemesi yapılmıştır. Sonlu hacimler yöntemine dayalı yapılan sayısal çözümde Standart k- $\varepsilon$ (SKE), Re-normalization Group (RNG), Kayma Gerilmesi Taşınımı (Shear Stress Transport-SST) ve Reynolds Gerilme Model (Reynolds Stress Model-RSM) türbülans modelleri, su hava arakesitinin belirlenmesinde ise akışkan hacimler yöntemi kullanılmıştır. Dört farklı durum için deneysel olarak ölçülen su yüzü profilleri sayısal olarak belirlenen su yüzü profilleri ile karşılaştırılmıştır. Ortalama karesel hata $(\mathrm{OKH})$ ve ortalama mutlak göreceli hata $(\mathrm{OMGH}) \mathrm{kriterleri}$ kullanılarak yapılan karşılaştırmalarda, Durum 1, 3, 4 akım koşullarında SKE türbülans modeli, Durum 2'de ise RSM türbülans modeli su yüzü profilini belirlemede diğer modellere göre daha başarılı sonuçlar vermiştir. Çalışmada, deneysel enerji kayıplarının yanında sayısal hız profilleri, hız vektörleri ve türbülans kinetik enerjilerin sıçrama bölgesindeki değişimleri değerlendirilmiştir.

\section{Anahtar Kelimeler- Sayısal Modelleme, Serbest Hidrolik Sıçrama, Su Yüzü Profili, Türbülans Modelleri}

\footnotetext{
1* Sorumlu yazar iletişim: gumus@harran.edu.tr (https://orcid.org/0000-0003-2321-9526) İșaat Mühendisliği Bölümü, Harran Üniversitesi, Şanlıurfa, Türkiye

2 İletişim:mhmtprmksz@gmail.com (https://orcid.org/0000-0002-3713-4323)

Inşaat Mühendisliği Bölümü, Harran Üniversitesi, Şanlıurfa, Türkiye

3 İletişim: oguzsimsek@harran.edu.tr (https://orcid.org/0000-0001-6324-0229)

Inşaat Mühendisliği Bölümü, Harran Üniversitesi, Şanlıurfa, Türkiye

4 İletişim: yavsaroglu@harran.edu.tr (https://orcid.org/0000-0003-0920-3202)

Inşaat Mühendisliği Bölümü, Harran Üniversitesi, Şanlıurfa, Türkiye
} 


\title{
Experimental and Numerical Modeling of Free Hydraulic Jump with Different Flow Conditions
}

\begin{abstract}
Hydraulic jump, defined as a rapid transition of flow from supercritical to subcritical, is often used to reduce the energy of water discharged from spillways with high velocities. It is important to know the characteristics of the hydraulic jump, which has a complex structure, for the design of stilling basin. In this study, experimental and numerical modeling of the hydraulic jump in different flow conditions are performed. SKE, RNG, SST and RSM turbulence models have been employed for the numerical analysis based on the finite volume method where, additionally, the free-surface modelling has been acquired by means of the volume of fluid (VOF) method. The experimentally measured surface profiles for four different cases are compared with the numerical surface profiles. In the comparisons mean square error (MSE) and mean absolute relative error (MARE) criteria are used. According to MSE and MARE, in Case 1, 3, 4 the SKE turbulence model and in Case 2 the RSM turbulence model provide more successful results than other models in determining the surface profile. In this study, in addition to experimental energy losses, changes in numerical velocity profiles, velocity vectors and turbulence kinetic energies in the jump region are evaluated.
\end{abstract}




\section{GIRIŞ}

Aşırı miktarda yağışın meydana gelmesi durumunda, baraj rezervuarında su seviyesi yükselmekte ve fazla suyun barajın üzerinden taşma riski meydana gelmektedir. Bu nedenle inşa edilen bir barajda gelecek taşkın sularının güvenli bir şekilde mansaba aktarılması amacıyla dolusavak olarak adlandırılan bir boşaltım sisteminin kurulması gerekmektedir. Dolusavaklar barajın üstünde, altında veya çevresinde bulunan ve taşkın sularını güvenli bir şekilde aktarmak için tasarlanan hidrolik yapılardır. Dolusavaklar barajların en önemli emniyet yapılarıdır. Birçok baraj, uygun olmayan dolusavak tasarımı veya yetersiz dolusavak kapasitesi nedeniyle yıkılmıştır $[1,2]$. Barajlarda bulunan dolusavaklar, yaklaşım kanalı, kret, kontrol kapakları, şüt kanalı ve enerji kırıcı yapılardan oluşur.

Dolusavak mansabında yer alan enerji kırıcı yapılar, fazla gelen suyun mansap tarafına emniyetli bir şekilde aktarılması amacıyla yapılan yapılardır. Bu yapılar ile dolusavaktan yüksek hızla çıkan suyun yüksek kinetik enerjisinin tüketilmesi ve güvenli (kritik altı akıma dönüşmüş) bir şekilde baraj mansabına aktarılması sağlanır. Suyun kinetik enerjisinin azaltılabilmesi için suyun, hidrolik mühendisliği alanında en ilginç olaylardan biri olarak kabul edilen hidrolik sıçrama sürecinden geçirilmesi gerekir. Hidrolik sıçramada akım, kritik üstü (sel rejimi) akımdan kritik altı (nehir rejimi) akıma hızlı bir geçiş sağlar ve bu geçiş esnasında aşırı derecede türbülans oluşur ve sıçrama bölgesinde büyük miktarda bir enerji sönümlenir. Hidrolik sıçramanın karakteristiklerinin bilinmesi bu enerji kırıcı yapıların tasarımında ve suyun güvenle mansaba aktarılması açısından önemlidir. Farklı araştırmacılar tarafından, hidrolik sıçramanın karakteristiklerinin belirlenmesine yönelik deneysel ve sayısal modellemeler ile ilgili araştırmalar yapılmıştır. Örneğin, Husain ve ark. [3], pozitif ve negatif basamak içeren eğimli dikdörtgen kesitli açık kanalda serbest hidrolik sıçramanın profilini deneysel olarak ölçmüşlerdir. Laboratuvar kanalında farklı Froude sayılarında ve kanal eğiminin \%2.5, \%5 ve \%7 olduğu durumda toplam 440 deney yapmışlardır. Çalışmalarında, eğimli kanalda ölçülen sıçrama uzunluğunu ve derinliğini tahmin etmek için regresyon analizi yapmışlar ve sıçrama uzunluğu ve derinliği ile ilgili yeni formüller önermişlerdir. Beirami, Chamani [4], çalışmalarında ogee profilli bir savak sonrası meydana gelen serbest hidrolik sıçramanın, sıçrama sonrası derinliğini ve sıçrama uzunluğunu farklı eğimlerde ölçmüşlerdir. Deneysel ölçümler, $40 \mathrm{~cm}$ genişliğinde ve $11 \mathrm{~m}$ uzunluğunda bir laboratuvar kanalında, kanal eğiminin $0,0.025$, $0.050,0.075$ ve 0.100 olduğu durumlarda yapılmıştır. Çalışmaları sonucunda, klasik hidrolik sıçramada meydana gelen enerji kaybının, kanal eğiminin negatif veya pozitif eğimlerde olduğu durumda oluşan diğer sıçrama türlerinden daha yüksek olduğunu tespit etmişlerdir. Abdel-Mageed [5], kanal eğiminin, kayar kapak sonrası meydana gelen serbest hidrolik sıçramanın karakteristikleri üzerine etkilerini araştırmıştır. Farklı akım durumlarında kanal eğiminin sıçrama sonrası derinlik ve sıçrama uzunluğu üzerine etkileri değerlendirmiş ve değerlendirme sonucunda kanal eğiminin ve buna bağlı olarak Froude sayısının artmasıyla sıçrama uzunluğunun arttığını belirtmiştir.

Bu deneysel çalışmaların yanında, bilgisayar teknolojisinde meydana gelen gelişmeler, bu tür akım problemlerinin sayısal modellenmesine imkân sunmaya başlamış ve bu sayısal modelleme teknikleri deneysel çalışmalara kıyasla daha az zaman ve maliyet gerektirmesinden dolayı birçok araştırmacının ilgisini çekmiştir. Fiziksel ve sayısal modelleme sonuçlarının karşılaştırılmasından, sayısal modelleme tekniklerinin hidrolik problemlerinin çözümünde güvenle kullanılacağı belirtilmiştir. Ebrahimi ve ark. [6], çalışmalarında üçgen ve dikdörtgen kesitli pürüzlü kanalda meydana gelen hidrolik sıçramayı standart k-E (SKE) türbülans kapatma modelini kullanarak iki boyutlu olarak modellemişlerdir. Serbest su yüzü profilini, akışkan hacimleri (Volume of Fluid-VOF) yöntemini kullanarak belirlemişlerdir. Froude sayısının 3 ile 7 arasında değiştiği 16 akım durumu için yapılan çalışma sonucunda, deneysel ve sayısal sonuçların oldukça uyumlu olduğu belirtilmiştir. Ayrıca, klasik hidrolik sıçramaya göre eğimli kanalda meydana gelen bu hidrolik sıçramada, enerji kaybı artarken, sıçrama sonrası derinliğin ve sıçrama uzunluğunun azaldığını belirlemişlerdir. Gümüş ve ark. [7], kayar kapak sonrası meydana gelen batmış hidrolik sıçramanın geometrisini farklı türbülans modellerini kullanarak modellemişlerdir. Sayısal modellemede serbest su yüzünün belirlenmesinde VOF yöntemini, türbülansın modellenmesinde ise Renormalization Group k- $\varepsilon$ (RNG), SKE ve Realizable k- $\varepsilon$ (RKE) türbülans kapatma modellerini kullanmışlardır. Çalışmanın sonucunda, RNG modelinin kullanılan diğer modellere göre serbest su yüzünü ve sıçrama geometrisinin modellemede daha başarılı olduğunu bildirmişlerdir. Babaali ve ark. [8], tarafından dinlendirme havuzunda meydana gelen hidrolik sıçramanın serbest su yüzü profili Flow-3D yazılımıyla modellenmiştir. Modelleme sonucunda elde edilen hidrolik sıçramanın karakteristikleri deneysel olarak elde edilen değerlerle karşılaştırılmıştır. Dinlendirme havuzu ve baraj mansabı çözüm alanı olarak 
değerlendirilmiş ve modellemede Navier-Stokes denklemleri kullanılmıştır. Türbülansın modellenmesinde, SKE ve RNG türbülans kapatma modelleri kullanılmış ve sayısal olarak hesaplanan basınç, hız, kinetik enerji ve Froude sayısı gibi bulgular İran'da bulunan Nazloo Barajı'nın fiziksel model sonuçları ile karşılaştırılmıştır. Çalışma sonucunda, fiziksel model sonuçları ile sayısal sonuçlar arasındaki korelasyonun iyi olduğunu belirlemişlerdir. Bayon ve ark. [9], serbest hidrolik sıçrama içeren düşük Reynolds sayılarına sahip akımı OpenFOAM ve FLOW-3D yazılımları ile sayısal olarak modellemişlerdir. Sayısal modellemede akımı idare eden temel denklemlerin çözümünde RNG türbülans kapatma modelini, serbest su yüzünün belirlemede ise VOF yöntemini kullanmışlardır. Deneysel olarak ölçülen sıçrama sonrası derinlik, sıçrama uzunluğu, akım ortalama hız profilleri ve serbest su yüzü parametreleri sayısal sonuçlarla karşılaştırılmıştır. Çalışma sonucunda, hidrolik sıçrama yapısını belirlemede OpenFOAM başarılı olurken; sıçrama sonrası derinlik, hız profili gibi parametrelerini hesaplamada ise FLOW-3D yazılımının daha başarılı olduğu belirtilmiştir. Şimşek ve ark. [10], çalışmalarında, dolusavak mansabında oluşan hidrolik sıçramanın su yüzü profillerini farklı Froude sayıları ve farklı yapı koşulları için deneysel ve sayısal olarak incelemiştir. Deneylerde su yüzlerinin ölçümü için limnimetre kullanılmış ve deney ile aynı koşullardaki akım için temel denklemler, sonlu hacimler yöntemine dayalı Hesaplamalı Akışkanlar Dinamiği (HAD) çözümlerinde sıklıkla kullanılan ticari bir yazılım olan ANSYSFluent paket programı kullanılarak iki boyutlu olarak çözülmüştür. Sayısal modellerden elde edilen su yüzü profilleri deneysel ölçümlerle karşılaştırılmış ve karşılaştırma sonucunda su yüzü profilinin belirlenmesinde, RSM modelinin kullanılan diğer modellerden daha başarılı olduğu görülmüştür. Mevcut çalışmalar incelendiğinde, farklı akım koşulları altında ve farklı kanal eğimlerinde sayısal modellemede kullanılan türbülans modellerinin başarısı farklılık göstermektedir.

$\mathrm{Bu}$ çalışmada, laboratuvar ortamında farklı akım özelliklerine sahip serbest hidrolik sıçramanın karakteristikleri deneysel olarak ölçülmüş ve elde edilen deneysel bulgular HAD yöntemleriyle farklı türbülans modelleri kullanılarak sayısal olarak modellenmiştir. Çalışma kapsamında, serbest hidrolik sıçramanın karakteristikleri deneysel ve sayısal olarak değerlendirilmiştir.

\section{MATERYAL VE YÖNTEM}

\section{A. Deneyler}

Teorik olarak, ani bir yüzey süreksizliği şeklinde ortaya çıkan ve Şekil 1'de görüldüğü gibi kritik-üstü rejimden kritik-altı rejime geçişi sağlayan sürece hidrolik sıçrama denir. Ancak, suyun hareket halinde olması nedeniyle, doğal ortamında bu sıçramanın, düşey bir yüzey süreksizliği yerine kanal boyunca belirli bir uzunluğa yayıldığı görülür. Hidrolik sıçramanın öncesindeki ve sonrasındaki su derinliklerine sırasıyla, $h_{1}$ ve $h_{2}$ derinliklerine eşlenik derinlikler denir. Su derinliğindeki bu ani yerel değişim sırasında akımda oluşan kuvvetli çalkantılar nedeniyle önemli ölçüde enerji kaybı (hidrolik sıçrama türüne göre hidrolik sıçrama öncesi akım enerjisinin \% 80-85'i oranına kadar) söz konusu olur. Hidrolik sıçramada meydana gelen enerji kaybı, Denklem 1 'de verildiği gibi hidrolik sıçrama öncesi enerjiden (1 nolu kesit), hidrolik sıçrama sonrası enerjinin (2 nolu kesit) çıkarılması sonucunda elde edilmektedir. Denklemde bulunan, g yer çekim ivmesini, $\mathrm{V}_{1}$ hidrolik sıçrama öncesi kesit ortalama hızını, $\mathrm{V}_{2}$ ise sıçrama sonrası kesit ortalama hızını temsil etmektedir.

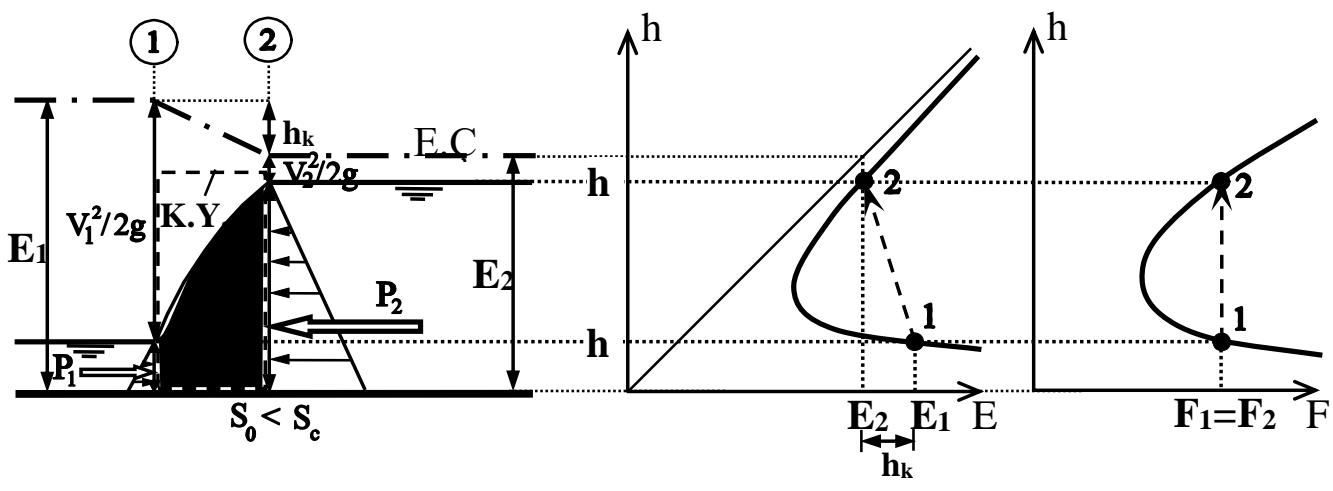

Şekil 1. Hidrolik sıçrama 


$$
E_{1}=\frac{V_{1}^{2}}{2 g}+h_{1} \quad E_{2}=\frac{V_{2}^{2}}{2 g}+h_{2} \quad h_{k}=E_{1}-E_{2}
$$

Deneyler, Harran Üniversitesi Mühendislik Fakültesi İnşaat Mühendisliği Bölümü Hidrolik Laboratuvarı'nda bulunan 35×35×400 cm boyutundaki açık kanal modelinde yapılmıştır (Şekil 2). Laboratuvarda bulunan kanalın tabanı ve yan duvarları cam olup, açık kanal modeline en fazla $\% 7$ eğim verilebilmektedir. Hidrolik sıçramanın yapısının ayarlanması için kanal memba kısmına bir kayar kapak yerleştirilmiş ve kanal sonuna bir savak yerleştirmek suretiyle farklı türlerde sıçramalar oluşturulmuştur. Su derinliği, su seviyesinin düzenli olduğu bölgelerde kanal üzerinde yerleştirilmiş olan dijital limnimetre ile sağlanmıştır. Debi değeri ise Altıgen marka bir elektromanyetik debi metre ile cihazın üzerindeki dijital panelden ölçülmüş olup, bu cihazın ölçüm hassasiyeti $\pm \%$ 0.6'dır.

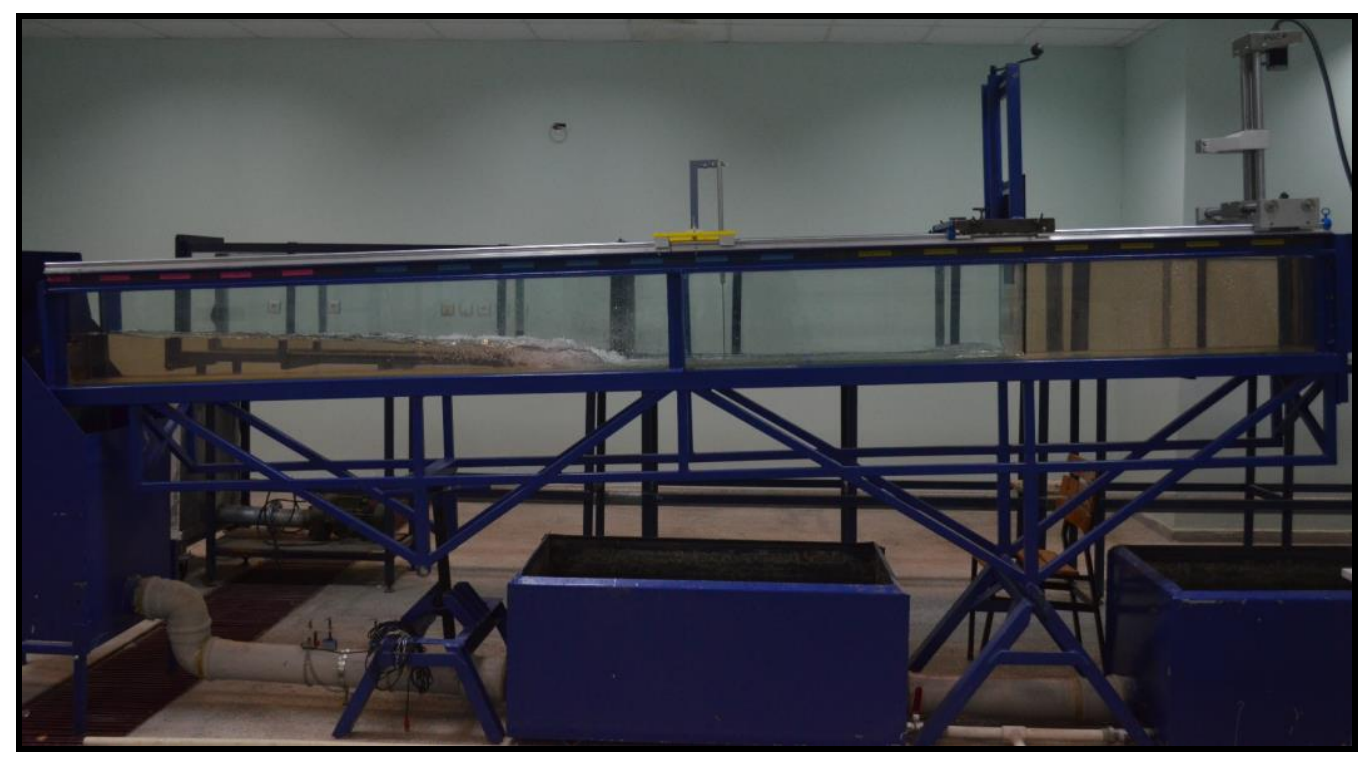

Şekil 2. Deneyde kullanılan açık kanal modeli

Sıçramanın türünün belirlenmesinde esas parametre sıçrama öncesi kesitte hesaplanan Froude sayısıdır. Froude sayısı Denklem 2'deki gibi hesaplanır.

$$
F r_{1}=\frac{V}{\sqrt{g h_{1}}}
$$

Farklı Froude sayıları ve kanal eğimlerine sahip serbest hidrolik sıçramanın değerlendirilebilmesi amacıyla dört farklı akım koşulunda deney yapılmış ve deney özellikleri Tablo 1'de verilmiştir.

Tablo 1. Hidrolik sıçramaya ait deneysel parametreler

\begin{tabular}{|c|c|c|c|c|}
\hline Durum & Debi $\left(\mathbf{m}^{\mathbf{3}} / \mathbf{s}\right)$ & hi $\mathbf{( m m})$ & Fr1 & Ĕgim (\%) \\
\hline $\mathbf{1}$ & 0.0102 & 23.8 & 2.54 & 0.80 \\
\hline $\mathbf{2}$ & 0.0103 & 20.1 & 3.29 & 0.80 \\
\hline $\mathbf{3}$ & 0.00662 & 12.5 & 4.31 & 4.96 \\
\hline $\mathbf{4}$ & 0.00647 & 9.1 & 6.77 & 4.96 \\
\hline
\end{tabular}


Şekil 3'te açık kanal akımında oluşan hidrolik sıçramanın şematik görünümü verilmiştir. Kanalda kritik üstü akımın meydana gelmesi için kanal membasına $(x=89 \mathrm{~cm})$ bir kayar kapak, kanal sonuna $(\mathrm{x}=400 \mathrm{~cm})$ ise keskin kenarlı bir savak yerleştirilmiştir. Durum 1, 2, 3 ve 4 için kayar kapak açıklığı sırasıyla 3.2, 2.8, 1.8 ve 1.4 $\mathrm{cm}$, kanal sonu keskin kenarlı savak yüksekliği (P) ise Durum 1 ve 2 için $3.8 \mathrm{~cm}$, Durum 3 ve 4 için ise $12 \mathrm{~cm}$ olarak ayarlanmıştır. Çalışma alanı olarak, sıçramanın başladığı noktanın $20 \mathrm{~cm}$ öncesi ve $130 \mathrm{~cm}$ sonrası ele alınmış ve bu 150 cm'lik bir bölge detaylı olarak incelenmiştir.

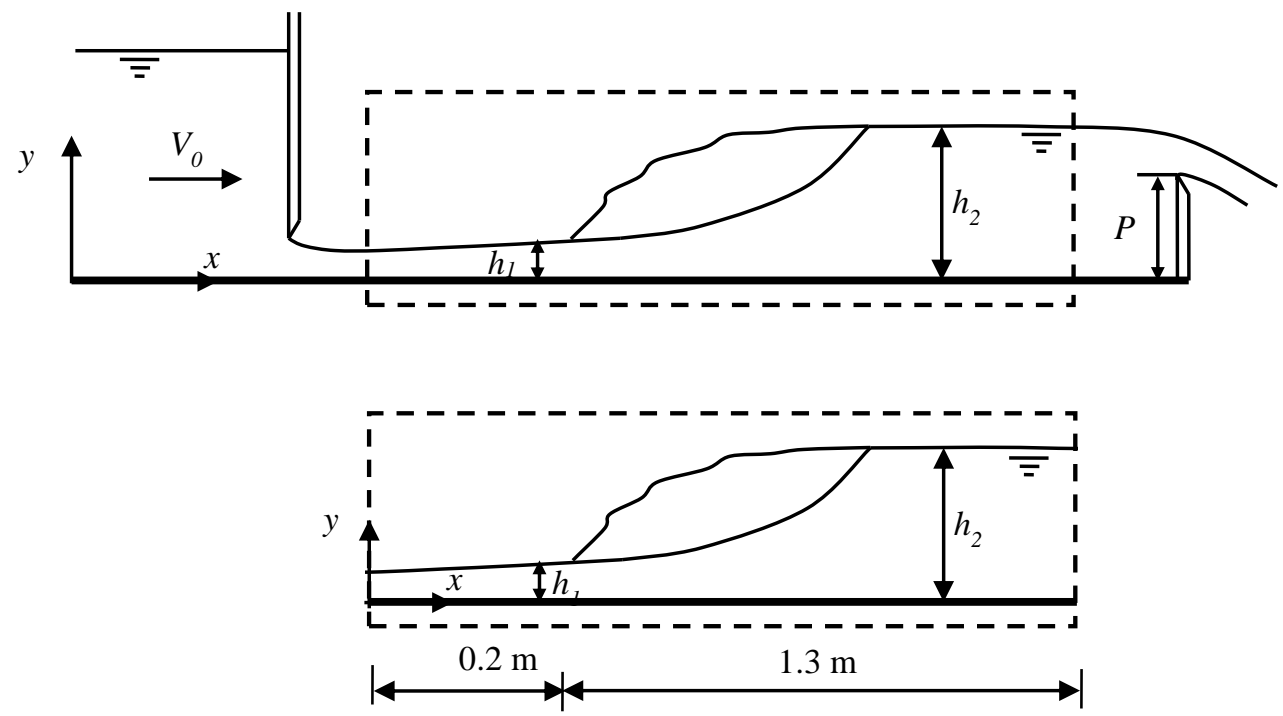

Şekil 3. Deney düzeneğinin şematik görünümü

\section{B. Yöntem}

1) Temel Denklemler: Serbest hidrolik sıçrama türbülanslı bir akım olup, akımın çözülebilmesi amacıyla kullanılacak temel denklemler süreklilik ve Reynolds Ortalamalı Navier-Stokes (RANS) denklemleridir ve bu denklemler sırasıyla, Denklem 3 ve 4'te verilmiştir.

$$
\begin{aligned}
& \frac{\partial u_{i}}{\partial x_{i}}=0 \\
& \rho\left(\frac{\partial u_{i}}{\partial t}+u_{j} \frac{\partial u_{i}}{\partial x_{j}}\right)=\rho g_{i}-\frac{\partial p}{\partial x_{i}}+\mu \frac{\partial^{2} u_{i}}{\partial x_{j}^{2}}+\frac{\partial}{\partial x_{j}}\left(\tau_{i j}\right)
\end{aligned}
$$

Süreklilik ve RANS denklemlerinde bulunan $\mathrm{u}_{\mathrm{i}}$ ortalama hız bileşenlerini, $\mathrm{p}$ ortalama basıncı, $\mu$ akışkanın dinamik viskozitesini, $\rho$ akışkanın yoğunluğunu, $\rho g i$ yerçekiminin sebep olduğu kütlesel kuvveti, $t$ zaman1, $\tau_{\mathrm{ij}}$ ise türbülans (Reynolds) gerilmelerini ifade etmektedir. Türbülans yani Reynolds gerilmeleri Boussinesq yaklaşımına göre Denklem 5'teki gibi ifade edilir:

$$
\tau_{i j}=-\rho \overline{u_{i}^{\prime} u_{j}^{\prime}}=\mu_{t}\left(\frac{\partial u_{i}}{\partial x_{j}}+\frac{\partial u_{j}}{\partial x_{i}}\right)-\frac{2}{3} \delta_{i j} \rho k
$$


Burada, $u_{i}^{\prime}$ ve $u_{j}^{\prime}$ türbülans hız sapınçları, $\mu_{t}$ türbülans viskozitesi, $\delta_{i j}$ Kronecker deltadır $\left(i=j\right.$ için $\left.\delta_{i j}=1\right)$.

2) Sayısal modelleme: RANS denklemlerinde üç boyutlu akışta bir basınç, üç hız, altı türbülans kayma gerilmesi bileşeni olmak üzere toplam 10 adet bilinmeyen bulunur. Buna karşılık her bir doğrultu için birer adet olmak üzere toplam üç adet RANS denklemi bileşeni ve bir süreklilik denklemi bulunmaktadır. Bilinmeyen sayısından az yani 10 bilinmeyene karşılık 4 denklem bulunduğundan denklem sistemi çözülememektedir. Bu sorunun çözümü için araştırmacılar tarafından farklı türbülans kapatma modelleri geliştirilmiştir. Bu çalışma kapsamında Standart k- $\varepsilon$ (SKE) [11], Renormalization Group k- $\varepsilon$ modeli (RNG) [12], Kayma Gerilmesi Taşınımı (Shear Stress Transport k- $\omega$-SST) [13] ve Reynolds Gerilme Modeli (Reynolds Stress Model- RSM) [14-16] olmak üzere toplam dört farklı türbülans modeli kullanılmıştır.

Su hava arakesitinin sayısal olarak belirlenebilmesi için akışkan hacimler yöntemi (Volume of FluidVOF) [17] kullanılmıştır. Akışkan hacimleri yönteminde, sayısal model çözüm ağının hacimsel doluluk oranını temsil etmesi için bir akışkan hacmi (F) tanımlanır. $F=1$ için ağ elemanı tam dolu, $F=0$ için boş (hava ile dolu) ve $0<\mathrm{F}<1$ için ağ elemanı kısmen dolu olmaktadır (Şekil 4). VOF yönteminde ara kesitin hesaplanmasında farklı yaklaşımlar bulunmakla beraber, bu çalışmada "Geo-Reconstruct" yaklaşımı kullanılmıştır.

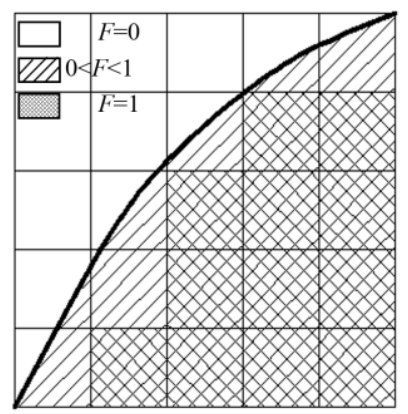

Şekil 4. A $\breve{g}$ elemanlarının doluluk oranları

3) Çözüm Bölgesi ve Sınır Şartları: Serbest hidrolik sıçramanın meydana geldiği dikdörtgen kesitli açık kanal akımının sayısal modeli için kullanılan çözüm bölgesi ve sınır şartları Şekil 5 'te verilmiştir. x, y koordinat sisteminin orijini, çözüm bölgesinin sol alt köşesi olarak alınmıştır. Şekilde verilen çözüm bölgesi, toplam beş alt bölgeye ayrılmış ve çözüm bölgesinin üst sınırı ve çıkış bölgesi sınır şartı $p=0$, kanal tabanında ve savak yüzeyinde sıfır-hız sınır şartı, yani $\mathrm{u}=0, \mathrm{v}=0$ olarak tanımlanmıştır. Giriş sınır şartı olarak v hızı sıfır olarak alınmış olup, yatay hız bileşeni u değeri her durum için deneysel verilerden ayrı ayrı hesaplanmıştır. Çözümde Durum 1 ve 2 için giriş hızı II. bölgeden, Durum 3 ve 4 için ise I. bölgeden verilmiştir. Oluşturulan III. bölgenin sınırı yine Durum 1 ve 2'nin kanal sonunda bulunan savağın yüksekliğine, IV. bölge ise Durum 3 ve 4 'ün savak yüksekliğine eşdeğer noktadan oluşturulmuştur. Zamana bağlı çözüm sürecinde, başlangıç şartı olarak, $\mathrm{t}=0$ anında boş olan çözüm bölgesinin giriş sınırında VOF yöntemi için $\mathrm{F}=1$, diğer bölgeler ve çözüm bölgesinin çıkış sınırında ise $\mathrm{F}=0$ alınmıştır. Sistemin açısı ilk iki durum için \%0.8, son iki durum için ise \%4.96 olarak yapılmıştır. 


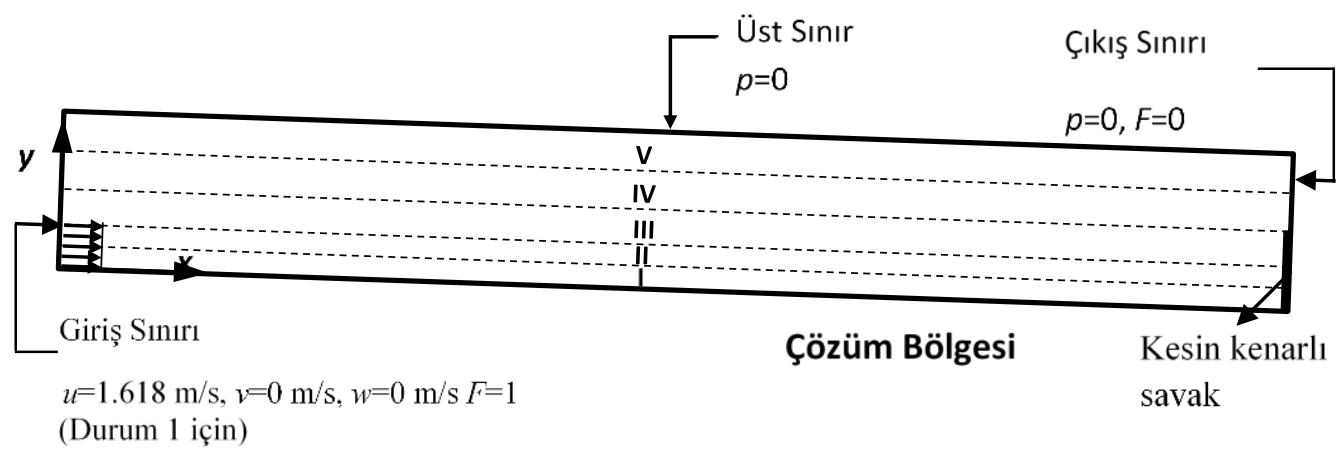

Şekil 5. Sayısal çözüm bölgesi ve sınır şartları

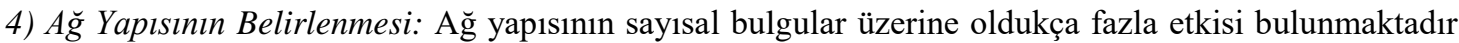
[18]. Bu nedenle hesaplama ağı tasarlanırken, ağ yapısının uygunluğunun test edilmesi gerekmektedir. Bu çalışma kapsamında oluşturulan modelin çözüm bölgesinde, hesaplama ağı beş alt bölgeye ayrılmış ve ağ yapısının sayısal çözüm değerleri üzerindeki etkisi incelenmiştir (Şekil 6). Ağ yapısı etkisi ile meydana gelecek ayrıklaştırma hatasının belirlenebilmesi için üç farklı yoğunlukta hesaplama ağı oluşturulmuş ve ağ yapısının her bir alt bölgesindeki eleman sayısı yaklaşık olarak \%25 ve \%50 oranında arttırılarak üç farklı yoğunluktaki hesaplama ağları kullanılmıştır. Tablo 2'de sayısal hesaplamalarda kullanılan üç farklı yoğunluktaki ağ yapısı için eleman sayıları verilmiştir.

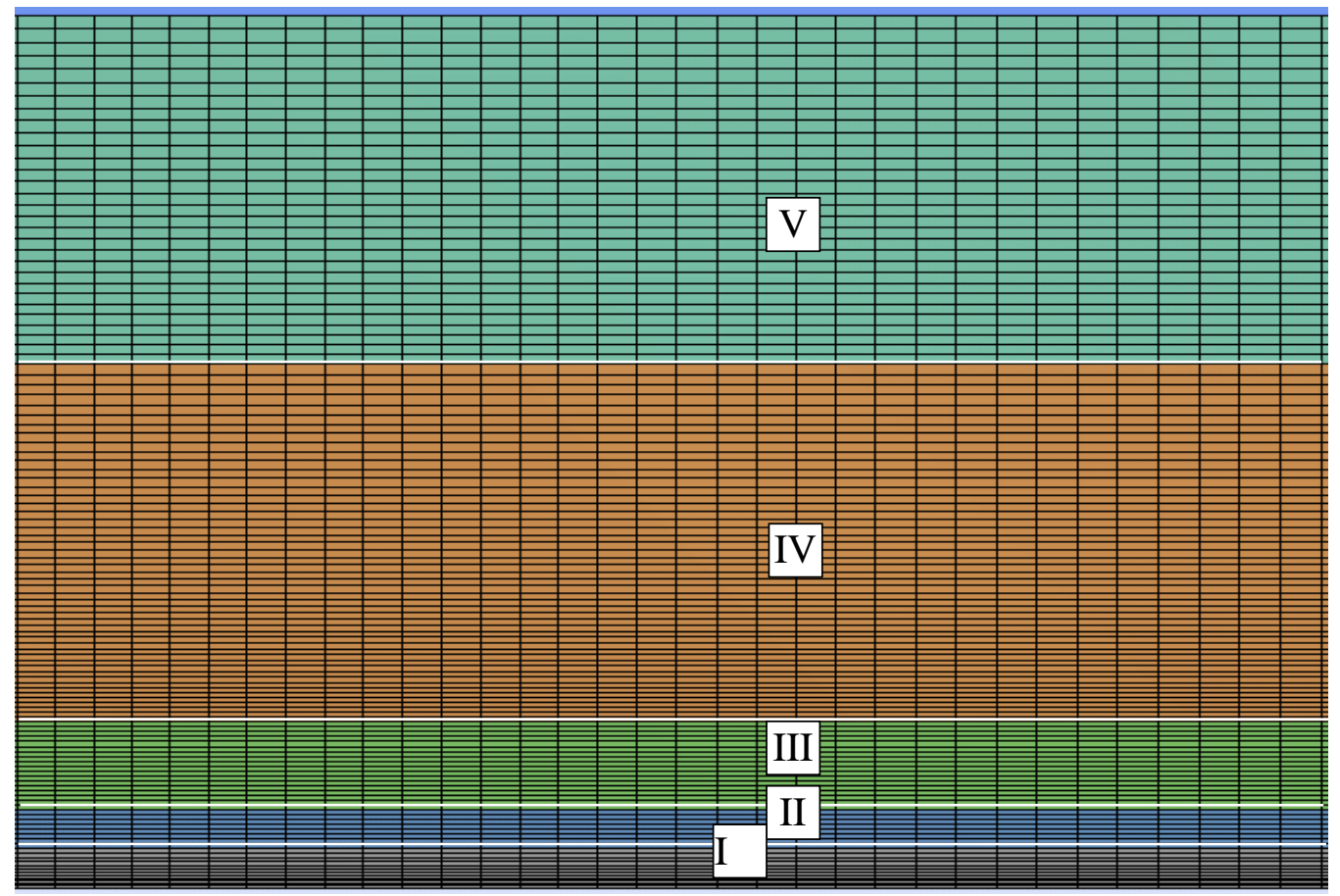

Şekil 6. Hesaplama ağı 
A ̆g yapısının sıklığının yeterliliği, yani sayısal çözümün ağ yapısından bağımsız olup olmadığının belirlenebilmesi için A ̆g Yakınsama İndeksi (Grid Convergence Index-GCI) [19-21] yöntemi kullanılmış ve

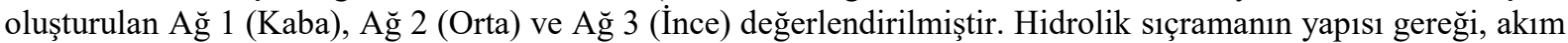
karakteristikleri (basınç, hız... vb.) zamana bağlı olarak oldukça hızlı değişim göstermektedirler. Bu nedenle, modelin $90 \mathrm{~s}$ boyunca çözümü yapılarak stabil olması sağlanmış ve $30 \mathrm{~s}$ daha çözüm yaptırılarak bu $30 \mathrm{~s}$ süresince alınan akım hızları, basınç değerlerinin ortalamaları alınmıştır.

Tablo 2. Farklı yoğunluktaki hesaplama ağlarına ait bölgesel eleman sayıları

\begin{tabular}{|c|c|c|c|}
\hline Bölge & A $\breve{g} 1$ (Kaba) & Ăg 2 (Orta) & $\mathbf{A \breve { g }} \mathbf{3}$ (İnce) \\
\hline 1 & $8 \times 200$ & $10 \times 250$ & $12 \times 300$ \\
\hline 2 & $6 \times 200$ & $7 \times 250$ & $8 \times 300$ \\
\hline 3 & $12 \times 200$ & $15 \times 250$ & $18 \times 300$ \\
\hline 4 & $33 \times 200$ & $42 \times 250$ & $50 \times 300$ \\
\hline 5 & $20 \times 200$ & $25 \times 250$ & $30 \times 300$ \\
\hline
\end{tabular}

Dört farklı duruma göre sayısal olarak en iyi tahminde bulunan model ile hidrolik sıçrama bölgesinde ve sıçrama sonrasında elde edilen maksimum $y^{+}$değerleri Tablo 3 'de verilmiştir. Buna göre, tüm çözüm alanı için en büyük $y^{+}$değeri tüm durumlarda sıçrama başlangıcında oluşmakta, anlık olarak artan bu $y^{+}$değerleri akım hızının ani değiştiği ve karmaşık bir yapı olan sıçrama başlangıcındaki jet akımının etkisiyle anlık olarak meydana gelmiştir. Hidrolik sıçramanın bitiminden sonra ise en büyük $y^{+}$değerleri hızın büyüklüğüne bağlı olarak 3.3 ile 4.1 arasında değişim göstermiştir. Sıçrama sonrası meydana gelen kritik altı açık kanal akımında elde edilen $y^{+}$değerlerinin Kırkgöz ve Ardıçlıoğlu (1994) tarafından önerilen 10 değerinden küçük olması nedeniyle uygun olduğu değerlendirilmiştir.

Tablo 3. Farklı bölgelere ait $y^{+}$değerleri

\begin{tabular}{|c|c|c|}
\hline Durum & Sıçrama Bölgesi Maks. $\boldsymbol{y}^{+}$ & Sıçrama Sonrası Maks. $\boldsymbol{y}^{+}$ \\
\hline $\mathbf{1}$ & 12 & 3.3 \\
\hline $\mathbf{2}$ & 13 & 3.7 \\
\hline $\mathbf{3}$ & 15 & 3.9 \\
\hline $\mathbf{4}$ & 16 & 4.1 \\
\hline
\end{tabular}

En yüksek Fr $_{1}$ sayısına sahip Durum 4 için $x=207$ cm'de GCI analizleri yapılmış ve sonuçlar Tablo 4'te verilmiştir. Bu kesitte beş farklı yükseklikte yapılan analizler sonucunda, ele alınan noktalarda $\mathrm{GCI}_{\text {ince }}$ değerlerinin en yüksek değeri \%1.02 olup, bu değer \%2'den küçük olduğu için, yani kabul edilebilir hata sınırında bulunması nedeni ile nümerik çözümde elde edilen hesaplama hassasiyetinin ağ yoğunluğundan bağımsızlaştığı kanaatine varılmıştır. Bu nedenle, sayısal modellemelere A $\breve{g}-3$ hesaplama ağı kullanılarak devam edilmiştir.

Tablo 4. $\mathrm{Fr}_{1}=6.77$ için $x=207 \mathrm{~cm}$ kesitinde elde edilen $\mathrm{GCI}_{\text {ince }}$ değerleri

\begin{tabular}{|c|c|c|}
\hline $\boldsymbol{y}(\mathbf{m m})$ & $\boldsymbol{p}$ & $\boldsymbol{G C I _ { \text { ince } } ( \boldsymbol { \% } )}$ \\
\hline 0.8 & 3.1613 & 0.83 \\
\hline 2.0 & -15.0849 & -0.52 \\
\hline 4.0 & 2.364 & 0.31 \\
\hline 5.5 & -3.1342 & -1.02 \\
\hline 7.5 & 1.8418 & 0.83 \\
\hline
\end{tabular}

III. BULGULAR VE YARTIŞMA

\section{A. Deneysel ve Sayısal Su Yüzü Profilleri}


Deneysel ve sayısal su yüzü profillerinin karşılaştırılmasında türbülans modellerinin başarısının belirlenmesi için niceliksel kriter olarak Denklem 6' daki gibi hesaplanan ortalama karesel hata $(\mathrm{OKH})$ ve Denklem 7'deki gibi hesaplanan ortalama mutlak göreceli hata (OMGH) kriterleri kullanılmıştır. Farklı akım durumlarında farklı türbülans modelleri kullanılarak elde edilen sayısal su yüzü profillerinin deneysel sonuçlar ile karşılaştırılması sonucunda hesaplanan $\mathrm{OKH}$ ve OMGH değerleri Tablo 5'te verilmiştir. Ele alınan akım koşullarında, Durum 2 hariç diğer akım durumlarında en küçük OKH ve OMGH değeri SKE türbülans modeli ile elde edilmiştir. Ayrıca bu değerler tablo içerisinde kalınlaştırılarak vurgulanmıştır. Durum 2' de ise RSM türbülans modeli en başarılı model olarak belirlenmiştir. Sayısal modellerin başarı sıralaması farklı akım durumlarda farklılık göstermiş olup, debi değişiminin model başarısını değiştirdiği görülmektedir.

$$
\begin{aligned}
& \mathrm{OKH}=\frac{1}{N} \sum_{n=1}^{N}\left(u_{d}-u_{h}\right)^{2} \\
& \mathrm{OMGH}=\frac{1}{N} \sum_{n=1}^{N}\left(\frac{\left|u_{d}-u_{h}\right|}{u_{d}}\right)
\end{aligned}
$$

Farklı akım durumlarında, farklı türbülans modelleri kullanılarak elde edilen sayısal su yüzü profillerinin deneysel profillerle karşılaştırılması Durum 1, 2, 3 ve 4 için sırasıyla Şekil 7, 8, 9 ve 10'da verilmiştir. Durum 1 için Şekil 7'de verilen su yüzü profilleri incelendiğinde SKE, RNG ve RSM türbülans modellerinin deneysel verilerle uyumlu tahminde bulunduğu görülmekte ve SST türbülans modelinin sıçrama bölgesinde su yüzü profilini başarılı olarak modelleyemediği, ancak sıçrama sonrası derinliği tüm modellerin başarılı bir şekilde modelleyebildiği görülmektedir. Şekil 8 'de verilen Durum 2 için elde edilen su yüzü profillerin karşılaştırılmasından, SST modelinin Durum 1'dekine benzer şekilde kullanılan diğer türbülans modellerine kıyasla daha başarısız olduğu, Durum 3'te ise su yüzünü belirlemede ele alınan tüm türbülans modellerinin başarısız olduğu belirlenmiştir (Şekil 9). Ancak, Durum 2 ve 3'te de siçrama sonrası derinlik deneysel verilere uyumlu bir şekil göstermiştir. Şekil 10'da sunulan su yüzü profillerinden ise SKE türbülans modelinin deneysel verilere en yakın tahminde bulunduğu görülmektedir. Ele alınan tüm akım durumlarında hidrolik sıçrama öncesi ve sonrasındaki akım derinliğinin genel olarak SKE, RNG, SST ve RSM türbülans modelleri ile başarılı modellendiği görülmekte ise de türbülans modellerinin başarısını, hidrolik sıçrama bölgesindeki su yüzü profilini tahmin etmedeki başarı oranı belirlemiştir.

Tablo 5. Tüm durumlar için elde edilen $O K H$ ve OMGH değerleri

\begin{tabular}{|c|c|c|c|c|c|c|c|c|}
\cline { 2 - 9 } \multicolumn{1}{c|}{} & \multicolumn{2}{c|}{ Durum 1 } & \multicolumn{2}{c|}{ Durum 2 } & \multicolumn{2}{c|}{ Durum 3 } & \multicolumn{2}{c|}{ Durum 4 } \\
\cline { 2 - 9 } \multicolumn{1}{c|}{} & $\begin{array}{c}\text { OKH } \\
\left(\mathbf{c m}^{2} / \mathbf{s}^{\mathbf{2}}\right)\end{array}$ & $\begin{array}{c}\text { OMGH } \\
(\boldsymbol{\%})\end{array}$ & $\begin{array}{c}\text { OKH } \\
\left(\mathbf{c m}^{\mathbf{2}} / \mathbf{s}^{\mathbf{2}}\right)\end{array}$ & $\begin{array}{c}\text { OMGH } \\
(\boldsymbol{\%})\end{array}$ & $\begin{array}{c}\text { OKH } \\
\left(\mathbf{c m}^{\mathbf{2}} / \mathbf{s}^{\mathbf{2}}\right)\end{array}$ & $\begin{array}{c}\mathbf{O M G H} \\
(\boldsymbol{\%})\end{array}$ & $\begin{array}{c}\text { OKH } \\
\left(\mathbf{c m}^{\mathbf{2}} / \mathbf{s}^{\mathbf{2}}\right)\end{array}$ & $\begin{array}{c}\text { OMGH } \\
(\boldsymbol{\%})\end{array}$ \\
\hline SKE & $\mathbf{0 . 3 1 4 0}$ & $\mathbf{7 . 9 8 1 5}$ & 0.1233 & 3.9395 & $\mathbf{1 . 1 0 9 9 5}$ & $\mathbf{1 5 . 5 9 0 5}$ & $\mathbf{0 . 2 8 0}$ & $\mathbf{8 . 0 0 6}$ \\
\hline RNG & 0.3350 & 8.0853 & 0.1768 & 4.2346 & 2.92131 & 23.6919 & 0.464 & 9.236 \\
\hline RSM & 0.3274 & 8.0045 & $\mathbf{0 . 1 2 0 8}$ & $\mathbf{3 . 8 5 4 4}$ & 3.16548 & 24.0711 & 0.564 & 10.674 \\
\hline SST & 0.3726 & 8.1268 & 0.7870 & 7.6710 & 1.39865 & 16.1533 & 0.506 & 10.266 \\
\hline
\end{tabular}



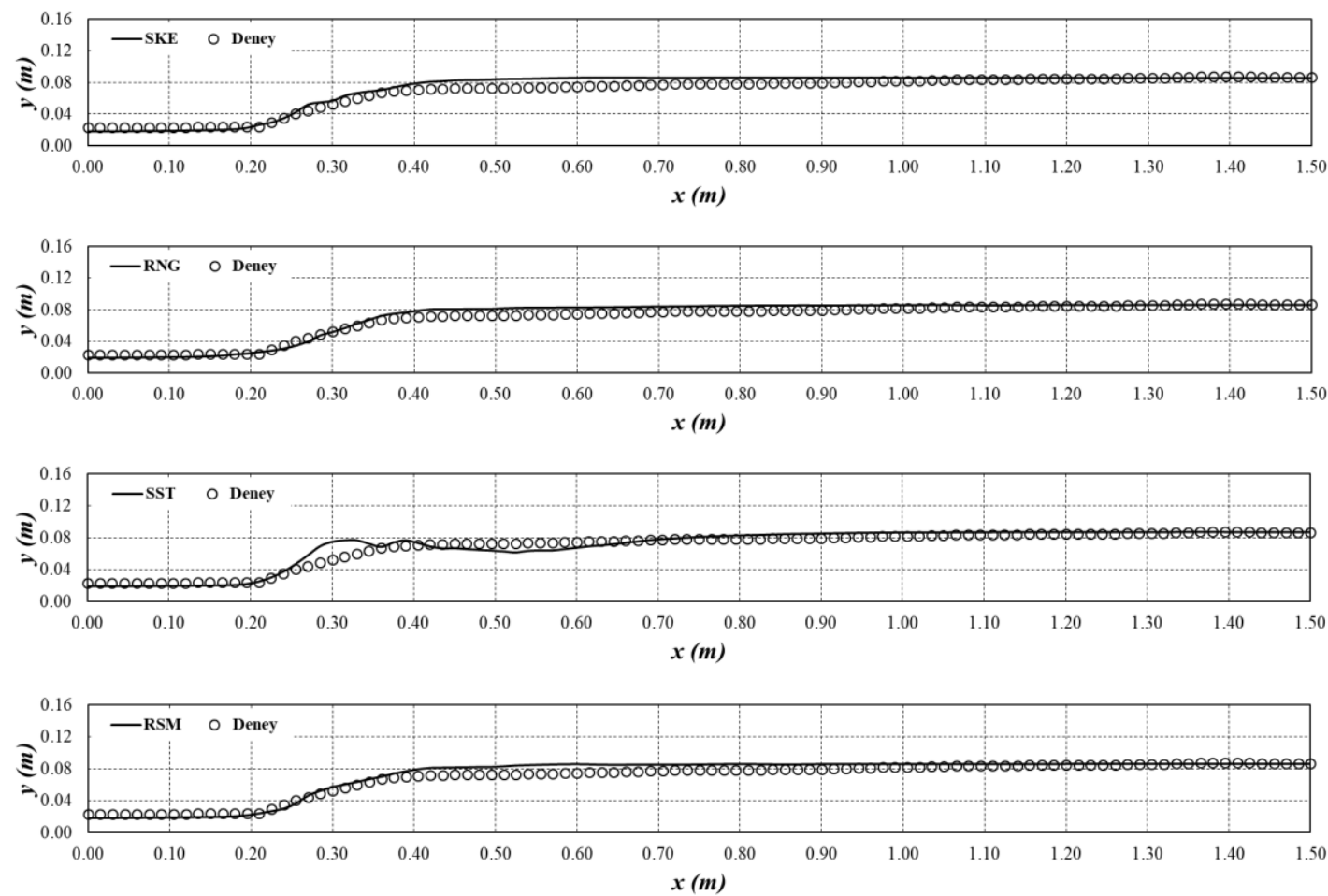

Şekil 7. Durum 1 için elde edilen sayısal ve deneysel su yüzü profilleri
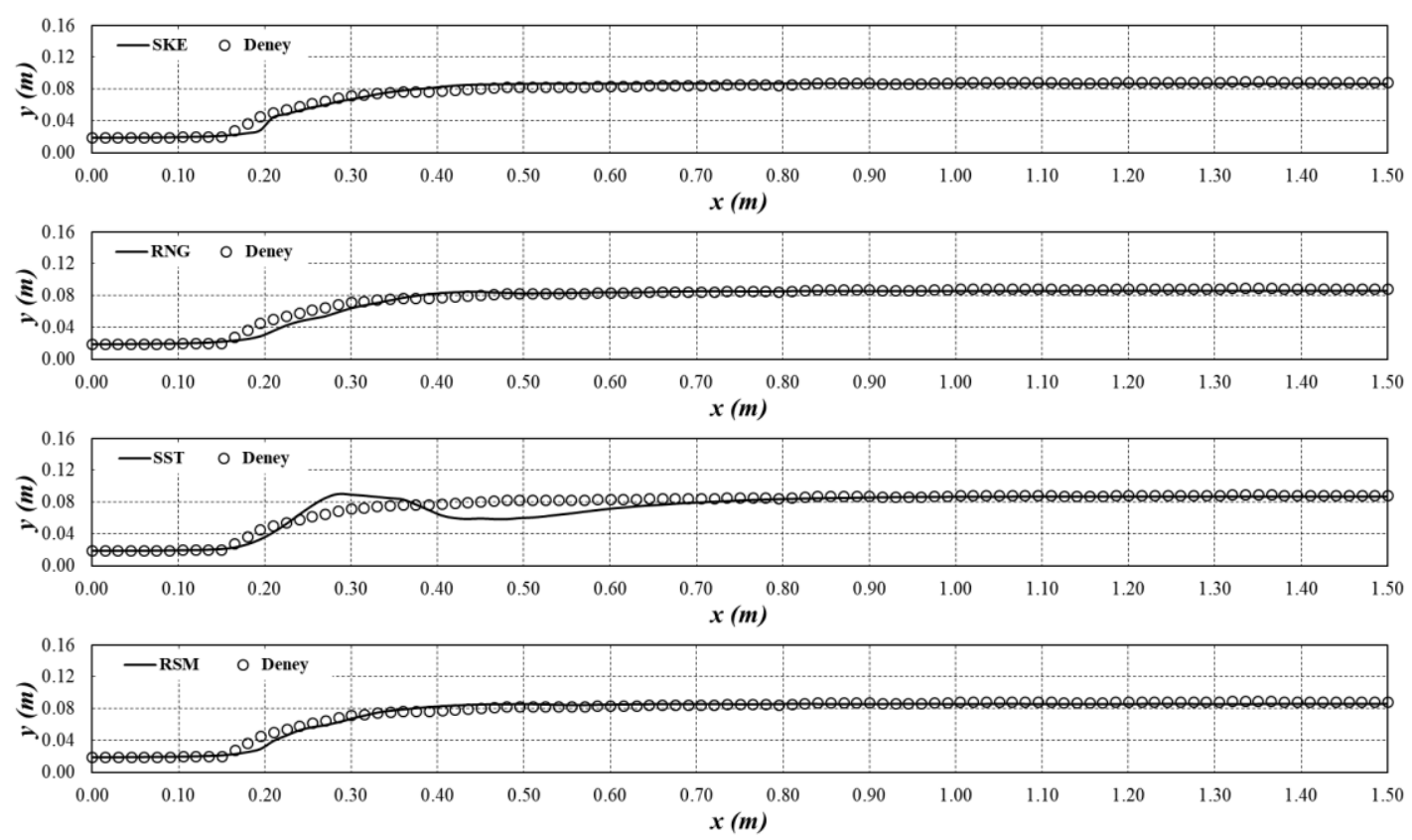

Şekil 8. Durum 2 için elde edilen sayısal ve deneysel su yüzü profilleri 

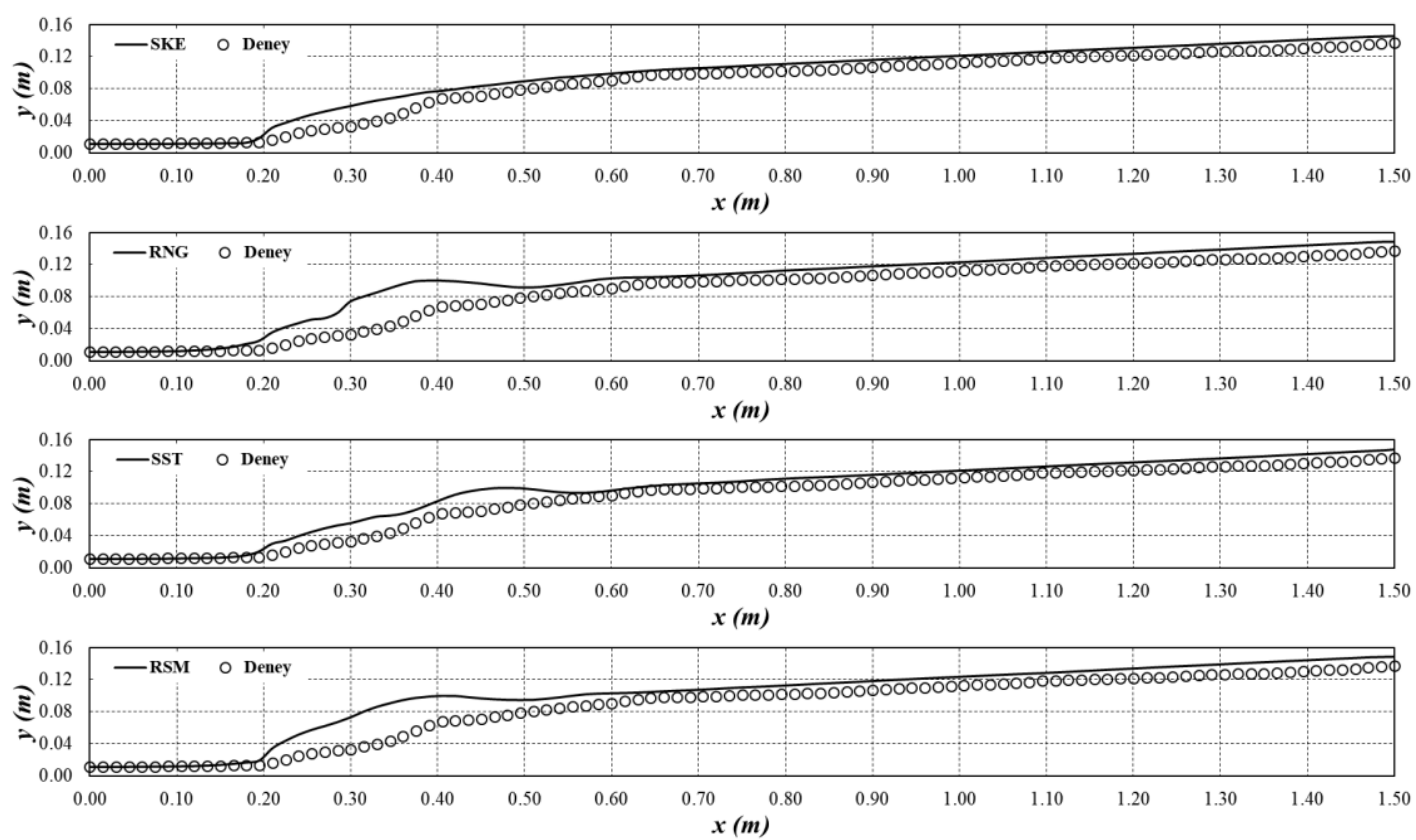

Şekil 9. Durum 3 için elde edilen sayısal ve deneysel su yüzü profilleri
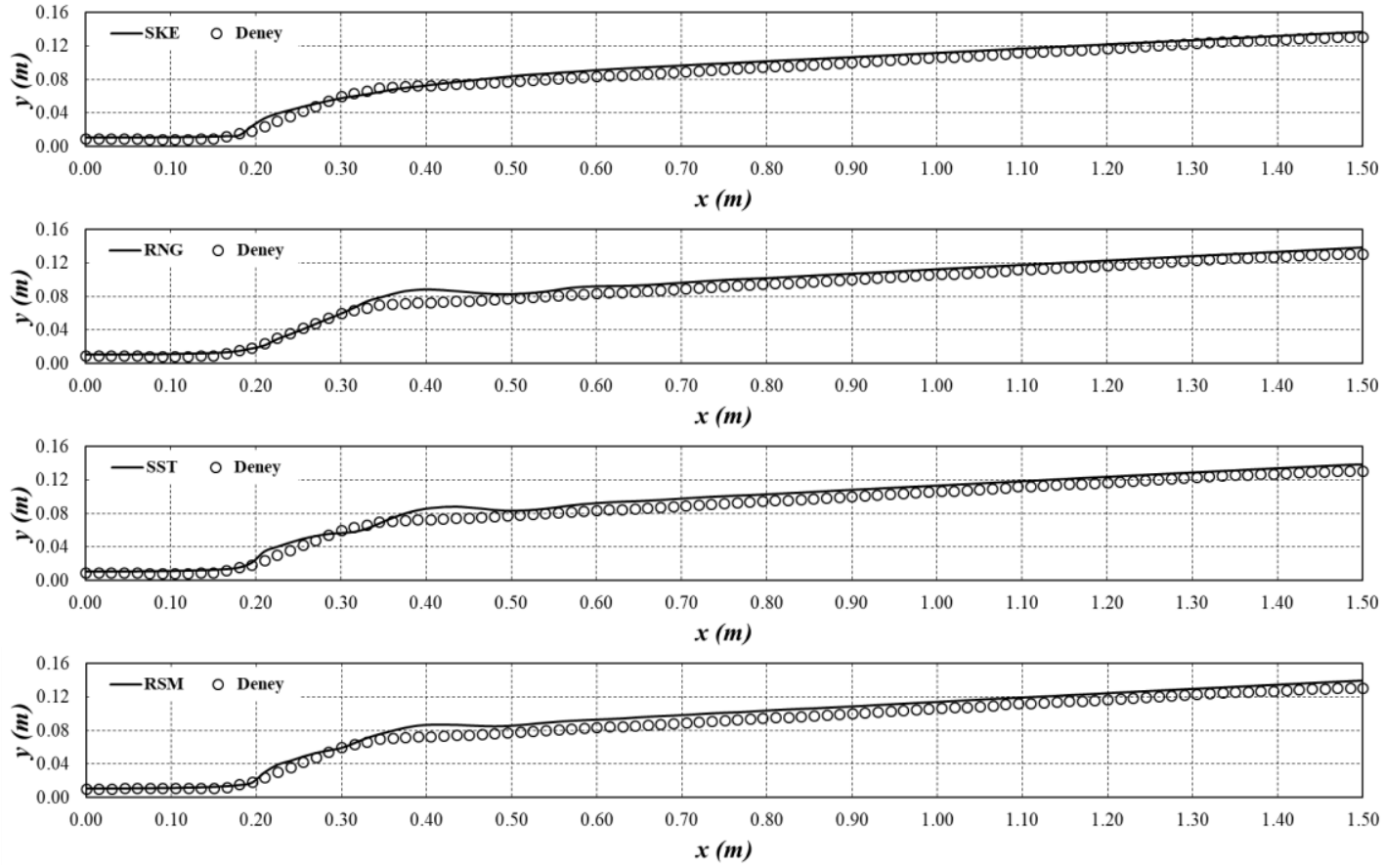

Şekil 10. Durum 4 için elde edilen sayısal ve deneysel su yüzü profilleri

\section{B. Sayısal Hız Profilleri}

Durum 1, 2 ,3 ve 4 için su yüzü profilini en başarılı olarak modelleyen türbülans modelleri kullanılarak elde edilen sayısal hız profilleri sırasıyla, Şekil 11, 12, 13 ve 14'te verilmiştir. Durum 1 için SKE modeliyle sayısal olarak hesaplanan hız profilleri incelendiğinde, sıçrama öncesi $(x=10 \mathrm{~cm})$ oluşan hız profillerinin ortalama hız değerleri $1.6 \mathrm{~m} / \mathrm{s}$ civarında olup klasik kritik üstü açık kanal akımına ait bir profil sergilemektedir. 
Sıçramanın başladığı noktadan $10 \mathrm{~cm}$ uzaklıkta bulunan $x=30 \mathrm{~cm}$ kesiti için SKE, kanal tabanına yakın olan bölgede yaklaşık $1 \mathrm{~m} / \mathrm{s}$ civarında maksimum hıza sahip bir jet akımı belirlediği ve su yüzeyine yakın bölgede ise düşük bir hızın meydana geldiği görülmektedir. Kanal sonuna doğru ilerledikçe su derinliğinin artmasına paralel olarak maksimum hızın azaldığ 1 görülmektedir. SKE modelinde jet akımının yaklaşık $x=65 \mathrm{~cm}$ 'de klasik açık kanal akım profiline yakın bir profil sergilediği ve çalışma alanının sonuna doğru ise açık kanal akım profili sergilediği yani sıçrama etkisinden kurtulduğu görülmektedir. Buna göre, sıçrama bölgesinin içinde yer aldığ çalışma alanı için farklı türbülans kapatma modelleri ile hesaplanan sayısal olarak hız profillerinin yapısı incelendiğinde, SKE modeli sıçrama sonlandıktan sonra elde dilen hız profilleri Mccorquodale, Khalifa [22] sonuçlarına benzer bir yapı sergilediği ve buna bağlı olarak su yüzü profilinin hesaplanmasında benzer bir şekilde hız profilini de belirlemede başarılı oldukları görülmüştür. Şekil 12, 13 ve 14'teki Durum 2, Durum 3 ve Durum 4'e ait hız profilleri inceldiğinde ise hız profillerinin Durum 1'e benzer olduğu, sadece akımın Froude sayısının büyümesi ile sıçrama uzunluğun arttığı, yani akımın klasik bir açık kanal akımına dönüşme mesafesinin büyüdüğü görülmektedir.

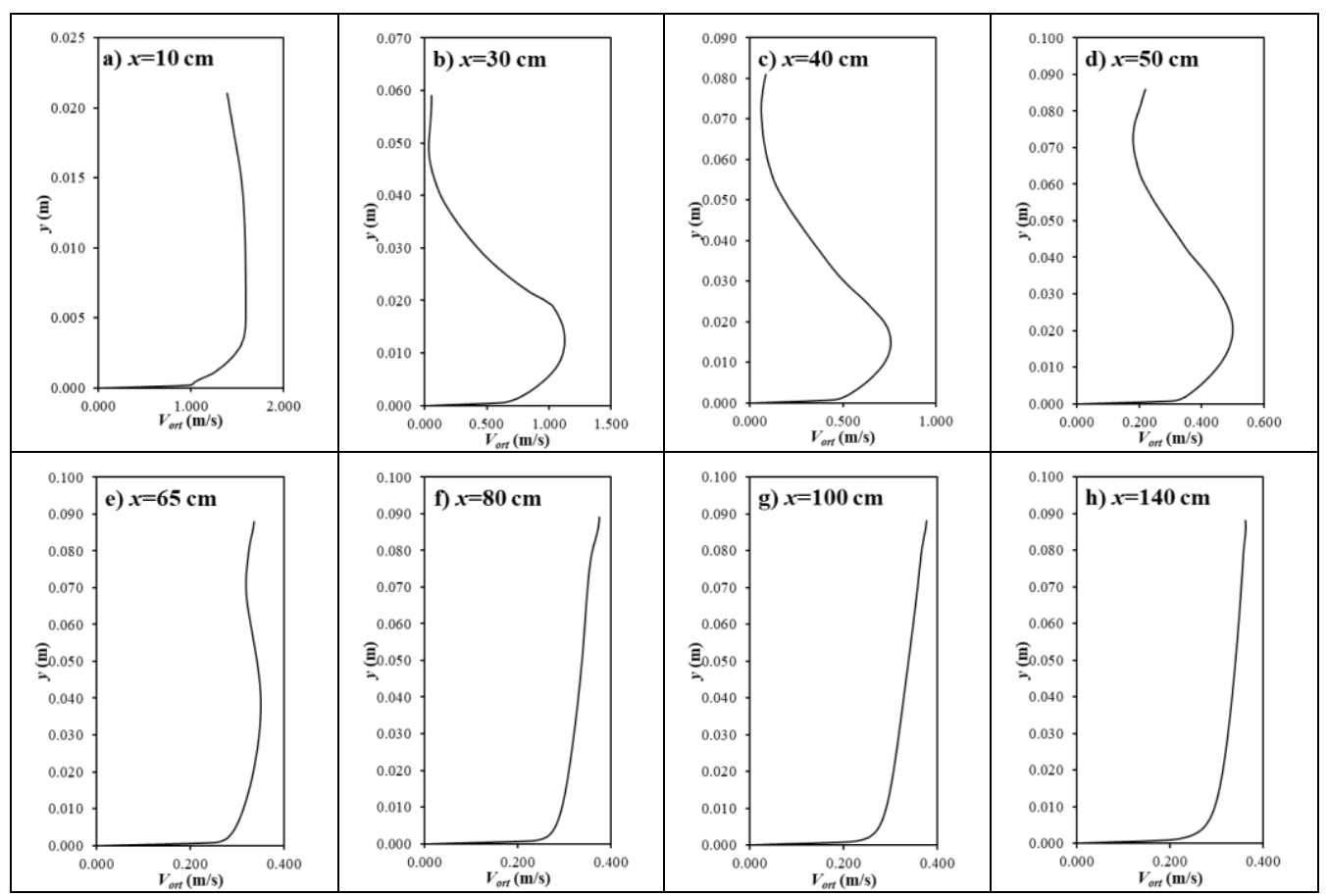

Şekil 11. SKE türbülans modeli ile elde edilen hız profilleri (Durum 1)

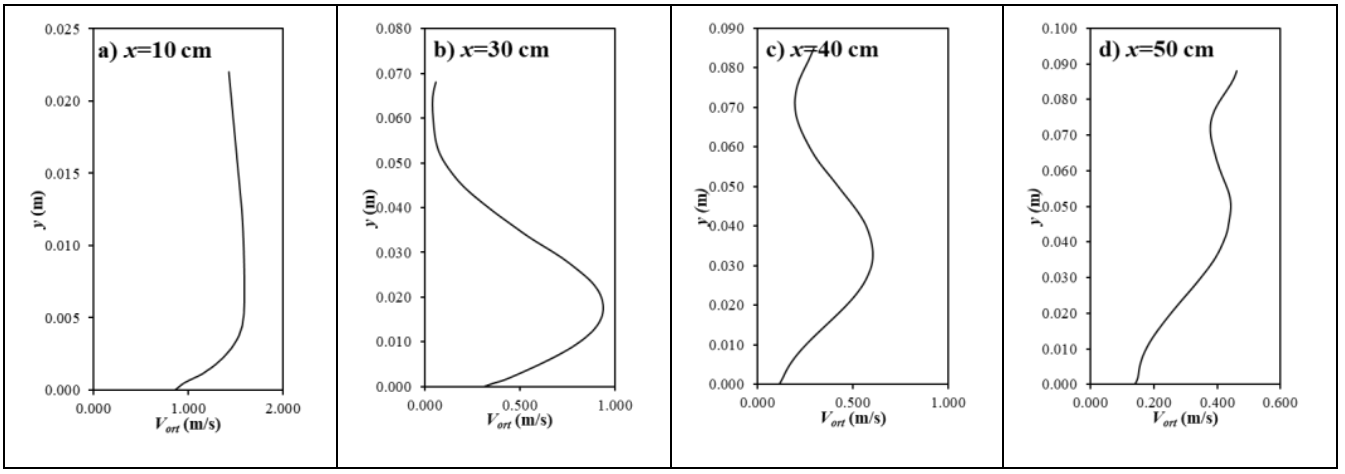




\begin{tabular}{|c|c|c|}
\hline & $\begin{array}{l}\text { BŞEÜ Fen Bilimleri Dergisi } \\
6(2), 447-466,2019\end{array}$ & $\begin{array}{r}\text { BSEU Journal of Science } \\
\text { DOI: } 10.35193 / \text { bseufbd.634637 }\end{array}$ \\
\hline $\begin{array}{l}\text { BiLECIK SEYHEEEBL } \\
\text { ON N I ERSITES }\end{array}$ & & e-ISSN: 2458-7575 (http://dergipark.gov.tr/bseufbd) \\
\hline
\end{tabular}

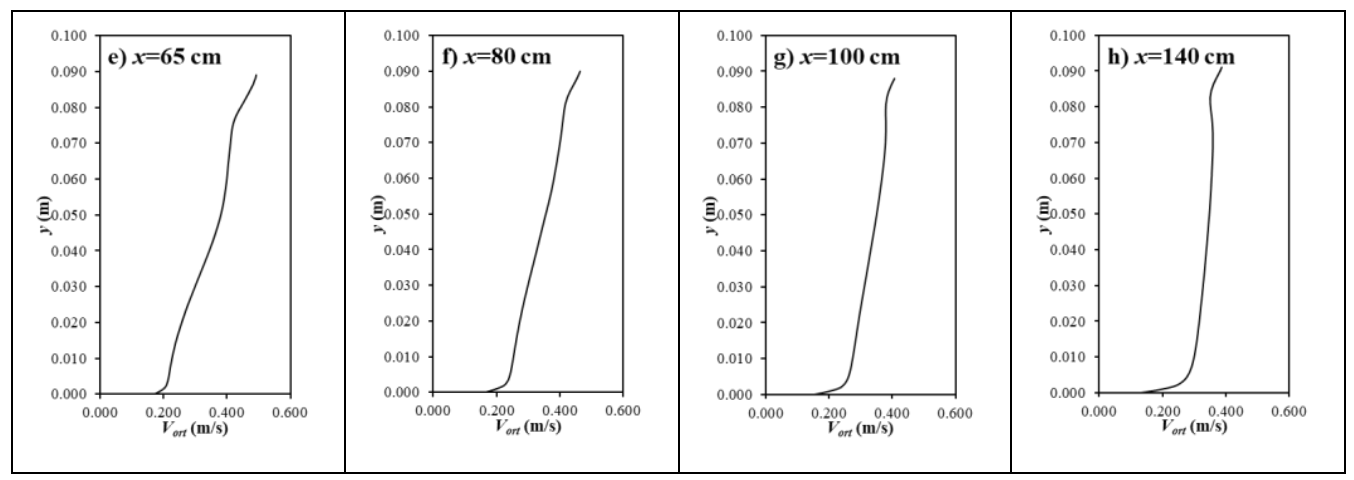

Şekil 12. RSM türbülans modeli ile elde edilen hız profilleri (Durum 2)

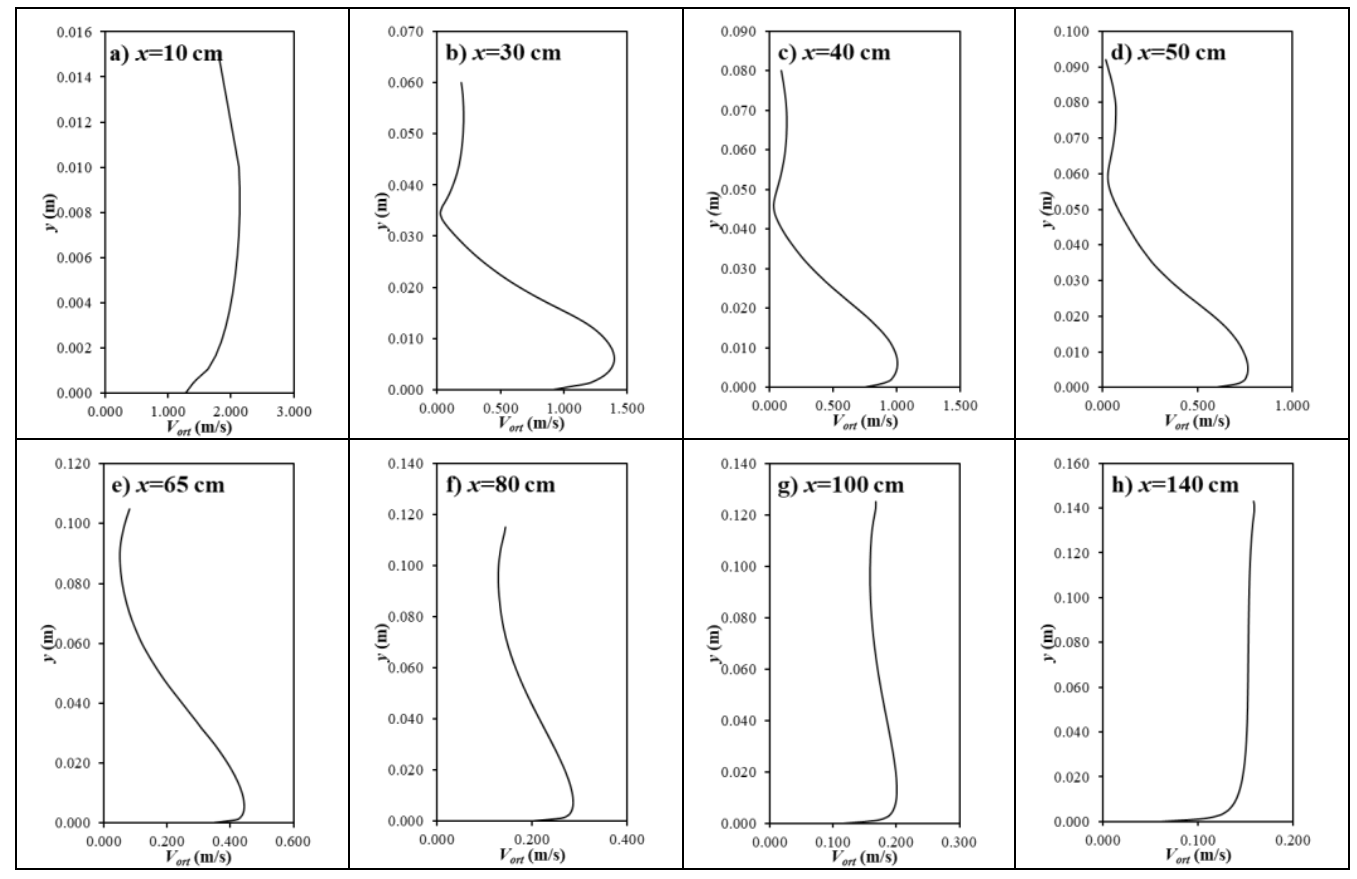

Şekil 13. SKE türbülans modeli ile elde edilen hız profilleri (Durum 3)

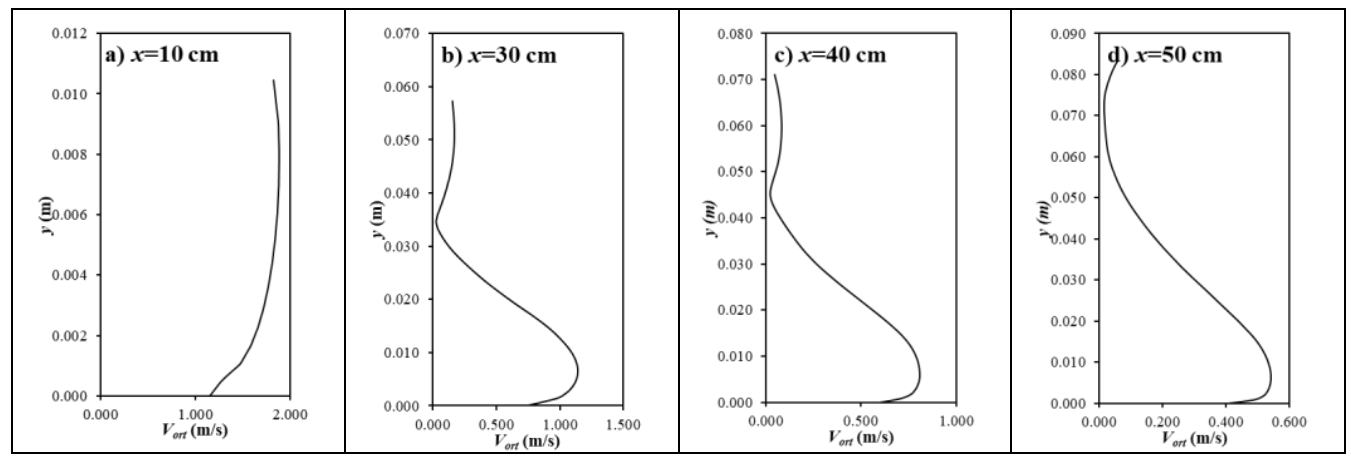



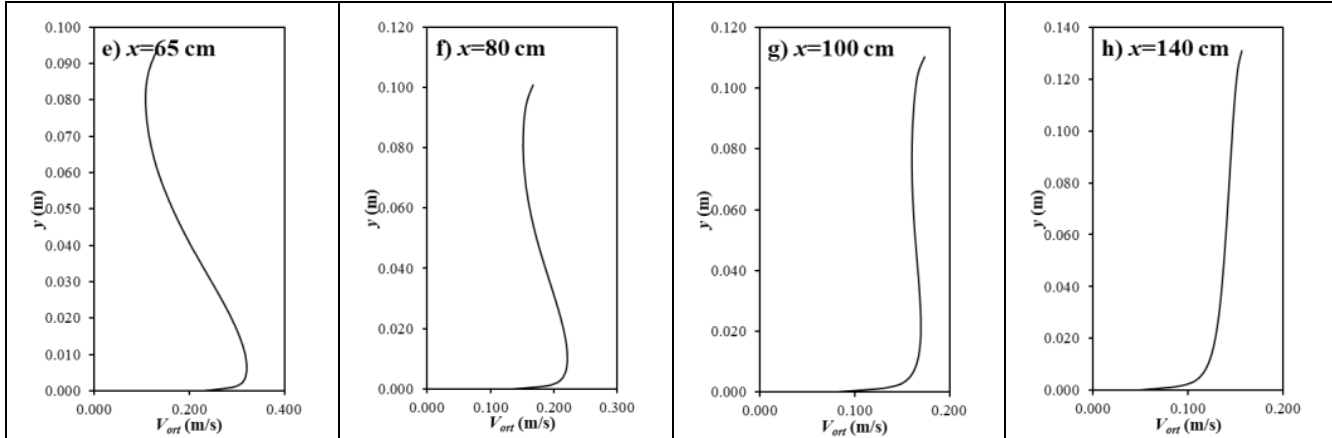

Şekil 14. SKE türbülans modeli ile elde edilen hız profilleri (Durum 4)

\section{Akım Çizgileri}

Su yüzü profillerinin deneysel veriler ile $\mathrm{OKH}$ ve OMGH kriterlerine göre karşılaştırılması sonucunda, en başarılı model olarak Durum 1, 3 ve 4 için SKE, Durum 2 için ise RSM modelinin olduğu belirlenmiştir. Bu nedenle, farklı akım durumları için su yüzü profilinin belirlenmesinde en başarılı türbülans modelleri ile elde edilen akım çizgilerinin deseni Şekil 15'te verilmiştir. Buna göre, en düşük Froude sayısına sahip Durum 1 akım koşulunda oluşan hidrolik sıçramanın zayıf, bunun yanında Froude sayısının artması ile sıçramanın uzunluğunun arttığı ve karmaşık bir yapıya dönüştüğü anlaşılmaktadır. Ayrıca, sıçrama bölgesi geri dönüş akımının olduğu bölgenin merkezinin Froude sayısının artmasıyla su yüzünden kanal tabanına kaydığı ve hidrolik sıçrama başlangıç noktasına doğru ilerlediği görülmektedir.
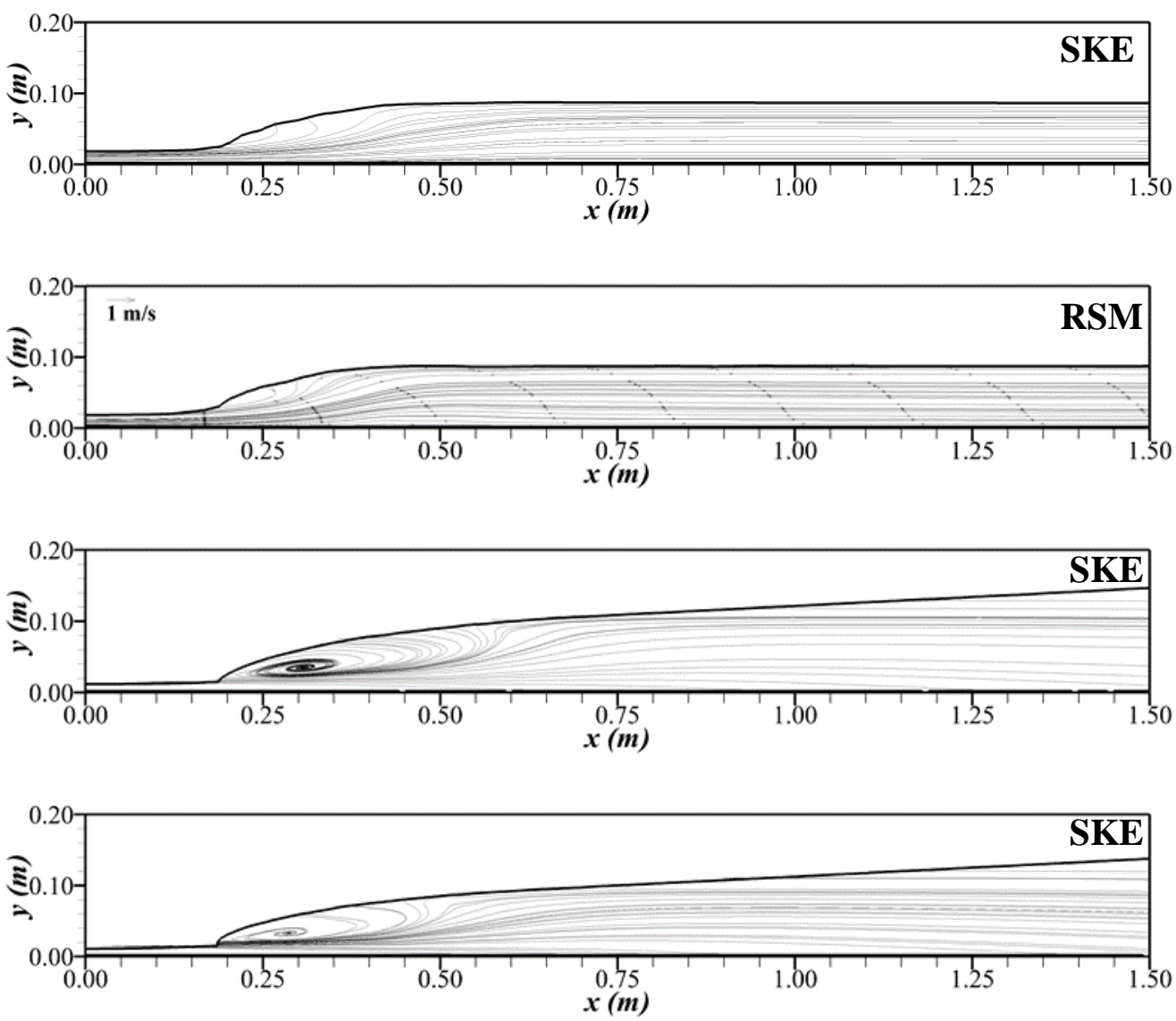

Şekil 15. Farklı akım durumları için elde edilen akım çizgilerinin deseni 


\section{Hız Vektörleri}

Şekil 16'da, farklı akım durumlarında en başarılı sonuçları veren türbülans modelleri ile elde edilen sayısal hız vektörlerinin desenleri verilmiştir. Şekiller incelendiğinde Froude sayısının artmasıyla birlikte, hidrolik sıçrama alt bölgesinde oluşan jet akımının büyüklüğünün arttığı ve sıçramanın etkisinin bittiği bölgede akımın tüm durumlarda klasik açık kanal akımına dönüştüğü tespit edilmiştir. Hidrolik sıçrama bölgesinde elde edilen hız vektörlerinden, hidrolik sıçrama bölgesinin üst kısmında geri dönüş akım bölgesinde okların akım yönüne ters yönde olduğu ve hız vektörlerinin deseninin akım çizgileriyle uyum içerisinde olduğu belirlenmiştir.
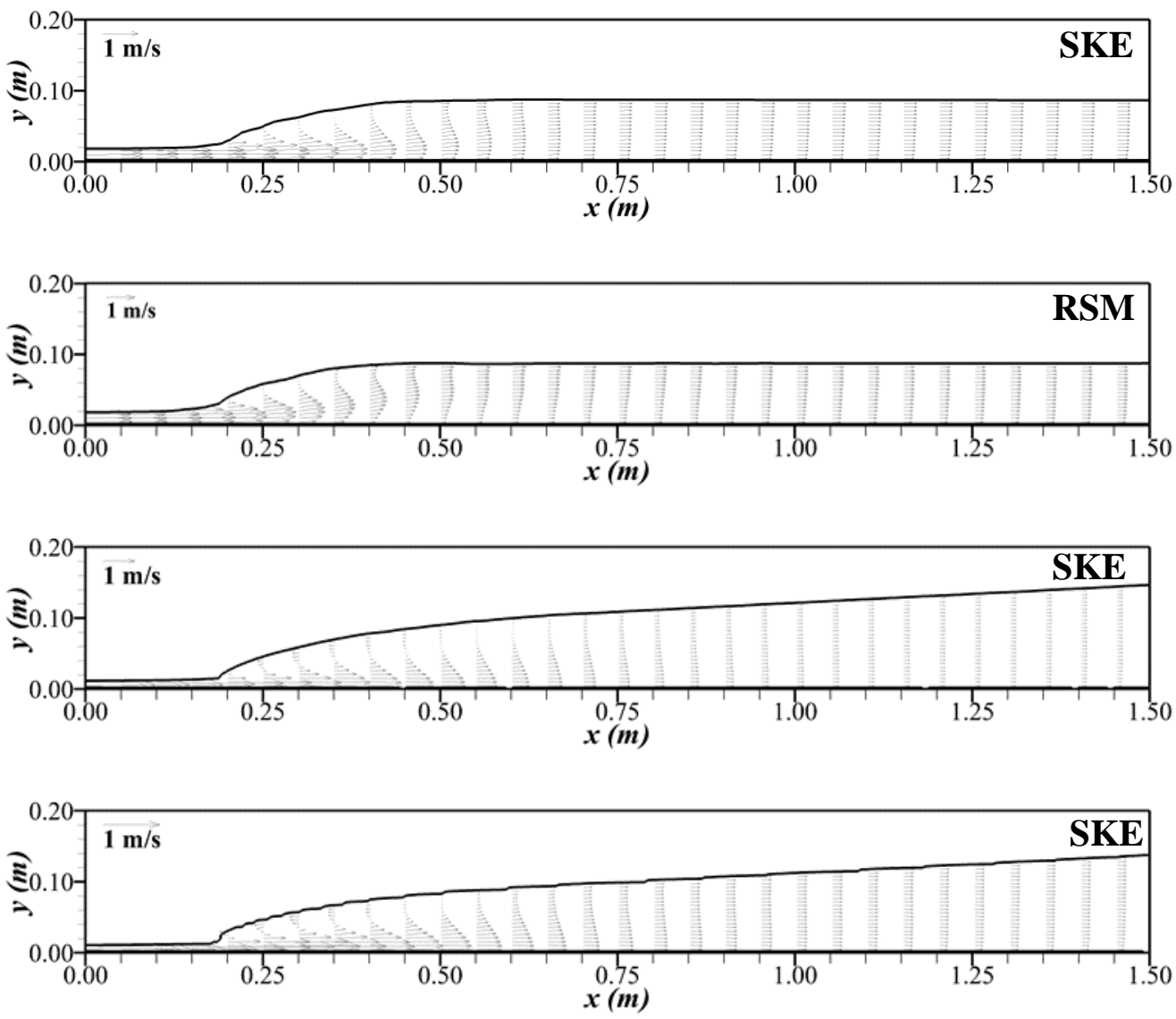

Şekil 16. Farklı akım durumları için elde edilen hız vektörlerinin deseni

\section{E. Türbülans Kinetik Enerjisi (TKE) Dă̆ılımı}

Farklı akım durumları için en başarılı sonuçları veren türbülans modellerinden elde edilen türbülans kinetik enerjinin (TKE) değişimi Şekil 17 'de verilmiştir. Froude sayısının artmasıyla hidrolik sıçrama mansabında oluşan akım derinliğinin arttığı ve bundan dolayı oluşan hidrolik sıçramanın uzunluğu, Froude sayısı artmasına rağmen azalma göstermektedir. Bunun yanında, Froude sayısının artmasıyla birlikte oluşan maksimum türbülans kinetik enerjinin görüldüğü bölgenin büyüdüğü görülmektedir. TKE grafiklerinde, aynı değişim bandı kullanılarak Froude sayısının değişimden kaynaklı TKE'deki değişimin daha iyi irdelenmesi amaçlanmıştır. Durum 2 akım koşulunda RSM türbülans modeli kullanılarak elde edilen TKE deseninden, Durum 1'e kıyasla daha küçük TKE değerlerinin oluştuğu görülmektedir. Hidrolik sıçrama bölgesi içinde hava kabarcıkların yüzey süreksizliğinin olduğu bölgede en büyük TKE değerlerinin oluştuğu açıkça söylenebilir. Hidrolik sıçramanın düzensizliği ve dinamik yapısından kaynaklı olarak hidrolik sıçrama içinde oluşan TKE dağılımı değişiklik 
gösterebilmektedir. Ayrıca, TKE değerlerinin maksimum olduğu bölgenin Froude sayısı ile değişimi akım çizgilerinin geri dönüş bölgesindeki değişimi ile paralellik göstermektedir.
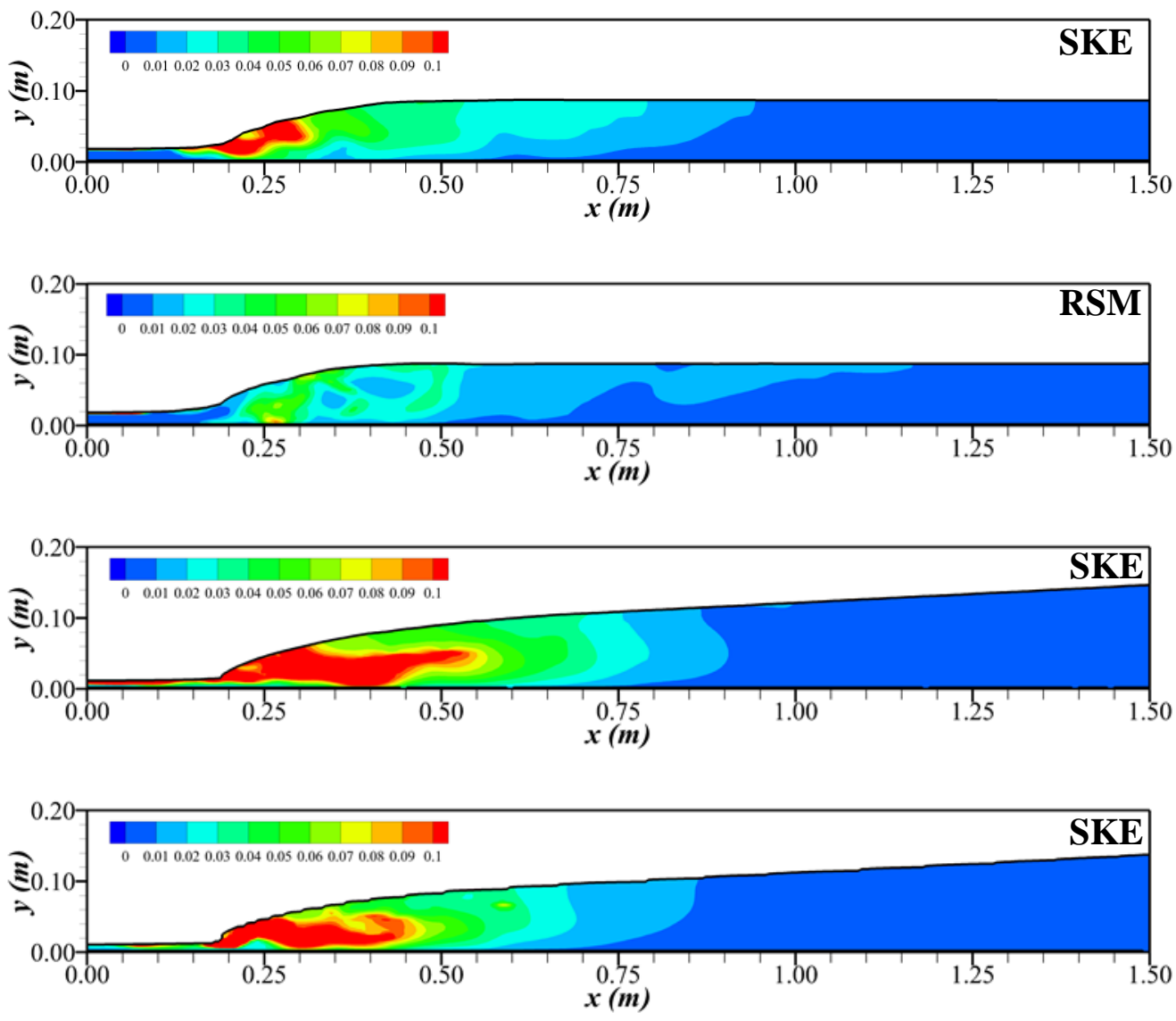

Şekil 17. Farklı akım durumları için elde edilen türbülans kinetik enerji deseni

\section{F. Enerji kayıplarl}

Dört farklı $\mathrm{Fr}_{1}$ sayısı için elde edilen deneysel ve sayısal model sonuçlarına göre hidrolik sıçramanın neden olduğu enerji kaybının belirlenebilmesi için, sıçrama öncesindeki toplam enerji değerinin sıçrama sonrasındaki azalma oranı belirlenmiş ve sıçramada meydana gelen toplam enerji kaybı hesaplanmıştır. Tüm durumlar için deneysel ve sayısal olarak elde edilen enerji kayıpları Tablo 6'da verilmiştir.

Tablo 6’ya göre, Durum 1'de deneysel olarak \%17.7'lik bir enerji kaybı belirlenirken, RSM modeli deneysel verilerle aynı enerji kaybı değerini, SKE modelinde ise deneysel enerji kaybından \%2 daha az bir enerji kaybı hesaplanmıştır. Durum 2'de, deneysel olarak hesaplanan \%25'lik enerji kaybı belirlenmiş, ele alınan tüm türbülans modelleri de bu değere yakın sonuçlar vermiştir. Durum 3'te deneysel olarak \%41.9'luk bir enerji kaybı hesaplanmış ve Durum 2'de olduğu gibi tüm türbülans modelleri bu enerji kaybına yakın bir değer vermişlerdir. En yüksek $\mathrm{Fr}_{1}$ değeri olan Durum 4'te ise deneysel olarak \%51.3'lük bir enerji kaybı meydana gelmiş, deneysel sonuçlara en yakın sonuçları ise SKE modeli \% 48.8 olarak vermiştir. Tüm durumlar beraber 
incelendiğinde elde edilen enerji kayıplarının literatür ile uyumlu olarak $\mathrm{Fr}_{1}$ değeri arttıkça arttığı ve deney koşulları ile elde edilen $\mathrm{Fr}_{1}=6.77$ ile \%50'nin üzerinde bir enerji kaybını belirlemede sayısal modellerin başarılı olduğu görülmüştür.

Tablo 6. Sıçrama nedeniyle meydana gelen deneysel ve sayısal enerji kayıpları

\begin{tabular}{|c|c|c|c|c|}
\hline Durum & Model & $\begin{array}{l}\text { Siçrama Öncesi } \\
\text { Toplam Enerji } \\
(\mathrm{m})\end{array}$ & $\begin{array}{c}\text { Siçrama Sonrası } \\
\text { Toplam Enerji } \\
(\mathrm{m})\end{array}$ & $\begin{array}{c}\text { Enerji Kaybi } \\
(\%)\end{array}$ \\
\hline \multirow{5}{*}{ 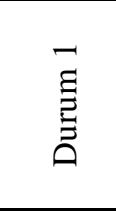 } & Deney & 0.101 & 0.083 & $\% 17.7$ \\
\hline & SKE & 0.101 & 0.085 & $\% 15.7$ \\
\hline & RNG & 0.104 & 0.089 & $\% 14.7$ \\
\hline & SST & 0.114 & 0.089 & $\% 21.8$ \\
\hline & RSM & 0.111 & 0.091 & $\% 17.7$ \\
\hline \multirow{5}{*}{ 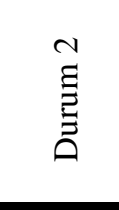 } & Deney & 0.125 & 0.094 & $\% 25.0$ \\
\hline & SKE & 0.122 & 0.093 & $\% 23.8$ \\
\hline & RNG & 0.120 & 0.091 & $\% 24.7$ \\
\hline & SST & 0.122 & 0.091 & $\% 25.2$ \\
\hline & RSM & 0.119 & 0.092 & $\% 22.4$ \\
\hline \multirow{5}{*}{$\stackrel{n}{\Xi}$} & Deney & 0.113 & 0.066 & $\% 41.9$ \\
\hline & SKE & 0.125 & 0.073 & $\% 41.6$ \\
\hline & RNG & 0.126 & 0.074 & $\% 41.0$ \\
\hline & SST & 0.124 & 0.073 & $\% 40.8$ \\
\hline & RSM & 0.127 & 0.075 & $\% 40.8$ \\
\hline \multirow{5}{*}{$\stackrel{+}{\Xi}$} & Deney & 0.117 & 0.057 & $\% 51.3$ \\
\hline & SKE & 0.125 & 0.064 & $\% 48.8$ \\
\hline & RNG & 0.120 & 0.064 & $\% 46.7$ \\
\hline & SST & 0.119 & 0.065 & $\% 45.4$ \\
\hline & $\mathrm{RSM}$ & 0.117 & 0.065 & $\% 44.4$ \\
\hline
\end{tabular}

\section{SONUÇLAR}

Farklı akım durumlarında oluşan hidrolik sıçramanın, deneysel ve sayısal modellenmesi yapılmıştır. Sayısal modellemede, sonlu hacimler yöntemine dayalı çözüm yapan HAD yazılımı yardımıyla türbülans gerilmelerinin tahmininde SKE, RNG, SST ve RSM türbülans modelleri, su hava arakesitinin belirlenmesinde ise akışkan hacimler yönteminden (VOF) yararlanılmıştır. Çalışmada elde edilen sonuçlar kısaca aşağıda özetlenmiştir;

- Deneysel ve sayısal su yüzü profillerinin OKH ve OMGH kriterlerine göre karşılaştırılmasında; Durum 1, 3, 4 akım koşullarında SKE türbülans modeli, Durum 2'de ise RSM türbülans modeli en iyi tahminde bulunmuştur.

- Sayısal olarak elde edilen hız profillerinden, akımın Froude sayısının büyümesi ile sıçrama uzunluğun arttığ1, yani akımın klasik bir açık kanal akımına dönüşme mesafesinin büyüdüğü görülmektedir. Bunun yanında, hidrolik sıçrama öncesi Froude sayısının artmasıyla, akım alanının daha da karmaşı hale geldiği belirlenmiştir.

- Sayısal akım çizgileri ve hız vektörlerinin deseninden hidrolik sıçrama alt bölgesinde katı sınıra yakın bölgesinde jet akımının varlığı görülmekte ve akım debisinin artmasıyla birlikte jet akımında görülen hız değerinin büyüklüğü artmakta, ayrıca sıçrama sonrasında ise klasik bir açık kanal akımı formuna dönmektedir. 
- Türbülans kinetik enerji desenlerinden hız profillerine benzer şekilde, hidrolik sıçramada büyük hızların ve türbülans şiddetinin olduğu bölgede türbülans kinetik enerji değeri de en büyük değerlere sahip olmaktadir.

- Hidrolik sıçrama bölgesinde meydana gelen enerji kaybı, türbülans kinetik enerji desenlerine benzer şekilde Froude sayısının artmasıyla büyüdüğü ve sayısal modelleme ile belirlenen enerji kaybının deneysel verilere uyumlu olduğu görülmüştür.

Sonuç olarak; farklı Froude sayılarına sahip serbest hidrolik sıçrama gibi karmaşık bir akım probleminin modellenmesinde, SKE ve RSM türbülans kapatma modellerinin akım hız alanı ve su yüzü profillerini belirlemede RNG ve SST modellerine kıyasla daha başarılı olduğu görülmüștür.

\section{TEŞEKKÜR}

Bu çalışma Harran Üniversitesi Bilimsel Araştırma Projeleri Koordinasyon Birimi (HÜBAP) tarafından desteklenmiştir (Proje No:19118).

\section{KAYNAKLAR}

[1] Smith, N. (1971). A history of dams. The Chaucer Press, London, UK., 279.

[2] Lempérière, F., Vigny J. \& Deroo L. (2012). New methods and criteria for designing spillways could reduce risks and costs significantly. Hydropower \& Dams, (3),120- 128.

[3] Husain, D., Alhamid A. A. \& Negm A.-a. M. (1994). Length and depth of hydraulic jump in sloping channels. Journal of Hydraulic Research, 32(6),899-910.

[4] Beirami, M. K. \& Chamani M. R. (2010). Hydraulic jump in sloping channels: roller length and energy loss. Canadian Journal of Civil Engineering, 37(4),535-543.

[5] Abdel-Mageed, N. (2015). Effect of Channel Slope on Hydraulic Jump Characteristics. Physical Science International Journal, 7(4),223-233.

[6] Ebrahimi, S., Salmasi F. \& Abbaspour A. (2013). Numerical study of hydraulic jump on rough beds stilling basins. Journal of Civil Engineering and Urbanism, 3(1),19-24.

[7] Gümüş, V., Aköz M. S. \& Kirkgöz M. S. (2013). Kapak Mansabında Batmış Hidrolik Sıçramanın Deneysel ve Sayısal Modellenmesi. Teknik Dergi, 24(117), 6379-6397.

[8] Babaali, H., Shamsai A. \& Vosoughifar H. (2014). Computational Modeling of the Hydraulic Jump in the Stilling Basin with Convergence Walls Using CFD Codes. Arabian Journal for Science and Engineering, 40(2),381-395.

[9] Bayon, A., Valero D., García-Bartual R., Vallés-Morán F. J. \& López-Jiménez P. A. (2016). Performance assessment of OpenFOAM and FLOW-3D in the numerical modeling of a low Reynolds number hydraulic jump. Environmental Modelling \& Software, 80,322-335.

[10] Şimşek, O., Aköz M. S., Soydan N. G. \& Gümüş V. Dolusavak Mansabında Oluşan Hidrolik Siçramanın Su Yüzü Profilinin Belirlenmesi. Harran Üniversitesi Mühendislik Dergisi, 3(3),31-37.

[11] Launder, B. \& Spalding D. (1972). Lectures in mathematical models of turbulence. Academic Press, London and New York, 169.

[12] Yakhot, V. \& Orszag S. A. (1986). Renormalization group analysis of turbulence. I. Basic theory. Journal of scientific computing, 1(1), 43-51. 
[13] Menter, F. R. (1994). Two-equation eddy-viscosity turbulence models for engineering applications. AIAA Journal, 32(8), 1598-605.

[14] Launder, B. E., Reece G. J. \& Rodi W. (2006). Progress in the development of a Reynolds-stress turbulence closure. Journal of Fluid Mechanics, 68(3),537-566.

[15] Gibson, M. M. \& Launder B. E. (2006). Ground effects on pressure fluctuations in the atmospheric boundary layer. Journal of Fluid Mechanics, 86(3),491-511.

[16] Launder, B. E. (1989). Second-moment closure and its use in modelling turbulent industrial flows. International Journal for Numerical Methods in Fluids, 9(8),963-985.

[17] Hirt, C. W. \& Nichols B. D. (1981). Volume of fluid (VOF) method for the dynamics of free boundaries. Journal of Computational Physics, 39(1),201-225.

[18] Gumus, V., Simsek O., Soydan N. G., Akoz M. S. \& Kirkgoz M. S. (2016). Numerical Modeling of Submerged Hydraulic Jump from a Sluice Gate. Journal of Irrigation and Drainage Engineering, 142(1),11.

[19] Roache, P. J. (1998). Verification of Codes and Calculations. AIAA Journal, 36(5),696-702.

[20] Akoz, M. S., Gumus V. \& Kirkgoz M. S. (2014). Numerical Simulation of Flow over a Semicylinder Weir. Journal of Irrigation and Drainage Engineering, 140(6), 04014016.

[21] Oner, A. A., Akoz M. S., Kirkgoz M. S. \& Gumus V. (2012). Experimental Validation of Volume of Fluid Method for a Sluice Gate Flow. Advances in Mechanical Engineering. 4, 461708.

[22] Mccorquodale, J. A. \& Khalifa A. (1983). Internal Flow in Hydraulic Jumps. Journal of Hydraulic Engineering, 109(5),684-701. 